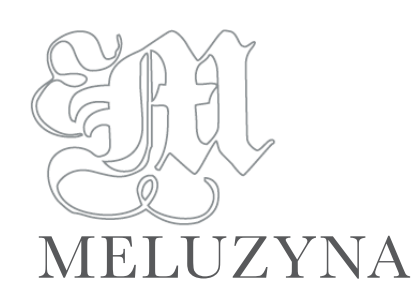

ISSN 2449-7339

1 (12) (2020) I Rocznik VII

DOI: $10.18318 / \mathrm{me} .2020 .1-05$

INEDITA

\author{
Natalia Czerniak $^{*}$ \\ Uniwersytet Gdański \\ ORCID ID 0000-0002-3217-0288
}

\title{
Wacława Potockiego Rozbój duchowny. Komentowana edycja krytyczna
}

Tematem poematu Wacława Potockiego Rozbój duchowny na drodze zbawiennej, napisanego z pewnością po 1677 i zapewne przed 1682 rokiem¹, jest kondycja człowieka, który nie potrafi dostrzec marności doczesnego świata. Początkowo twórca skorzystał z przykładu Żydów, aby na kanwie biblijnej historii narodu wybranego wyjaśnić, dlaczego zaprzepaścił on szansę na zbawienie (w. 1-89). W kolejnych ustępach odwołał się do własnego życia. Ułuda szczęścia prysła, gdy umarły dzieci poety. Autor zaczyna zgłębiać mierność dotychczasowej egzystencji, a jej transformacja dopełnia się w trakcie ataku pięciu metafizycznych przeciwników. Wątłego człowieka ratuje Jezus, nowy Samarytanin (w. 90-392). Nawrócony bohater docenia miłosierdzie Boga i pragnie zostać Jego rycerzem (w. 393-532). Utwór kończy modlitewna prośba, by w trakcie sądu ostatecznego zatryumfować nad wrogimi siłami, atakującymi każdego chrześcijanina (w. 533-542).

Idea żołnierza Chrystusowego, zaczerpnięta z Listu do Efezjan (Ef 6, 11-20), to jeden z częściej eksplorowanych motywów w twórczości łużeńskiego artysty. Jak wskazuje Radosław Grześkowiak, bezpośrednią inspiracją była dla Potockiego rycina Spirituale Christiani militis

\footnotetext{
e-mail autorki: n.czerniak.97@wp.pl

1 Terminus post quem wyznacza wzmianka o śmierci dzieci poety, Stefana (1673) oraz Zofii (1677) (w. 105-106), terminus ante quem jest przypuszczeniem Leszka Kukulskiego (1962, s. 122).
} 
certamen Hieronima Wierixa². W Rozboju duchownym koncentruje się wyłącznie na sposobie ukazania walki duchowej - rycerza otaczają Szatan, Grzech, Śmierć, Świat oraz Ciało ${ }^{3}$. W utworze brak odwołań do cytatów biblijnych wykorzystanych przez antwerpskiego grafika (poza wersetem o broni szatana) ${ }^{4}$. Potocki posługuje się alegoryczną wykładnią dramaturgicznej sceny, by przedstawić parenetyczny wzór rycerza, którym powinien się stać każdy chrześcijanin chcący służyć Bogu i zostać zbawionym, oraz przestrzec przed czyhającymi niebezpieczeństwami. Odwołania autobiograficzne sprawiają natomiast, że tekst charakteryzuje się większą sugestywnością. Dzięki temu poeta unika jałowego moralizatorstwa, o co wcale nietrudno w dziełach podejmujących tematykę dydaktyczną.

\section{Opis źródła}

Tekst poematu zachował się w postaci czystopisu sporządzonego ręką Potockiego w kodeksie z drugiej połowy XVII wieku (rkps Biblioteki Narodowej, sygn. 3047/III, in folio, kart 203). Zasadnicza część poetyckiej sylwy zapisana została przez cztery różne ręce, a pojedyncze wiersze na końcu manuskryptu (k. 202v-203v) zanotowały trzy kolejne. Rękopis przetrwał w formie 14 luźnych składek 5 .

Właściciela kodeksu wskazuje nota proweniencyjna na k. 1r: „Andrzej Jan z Lubieńca Lubieniecki s[karbnik] d[obrzyński] $m$ [anu propria] possesor". Ponadto na marginesie k. 198v umieszczono nazwisko: „Salomea Branicka”.

Manuskrypt zawiera głównie utwory Potockiego: Pieśni pokutne składania Jego M[oś]ci Pana Wacława z Potoka Potockiego podczaszego krakowskiego, przypisane Jaśnie Wielmożnej Jej M[oś]ci Paniej Helenie z Tęczyna Lubomierskiej wojewodzinej krakowskiej (k. 1r-41r), Nowy zaciag pod choragiew starą tryumfującego Jezusa Syna Bożego nad Światem, Śmiercia i Piekłem [...] roku Pańskiego 1679 dnia 1 Aug[usta] (k. 42r-113r), Siedm pieśni na siedm artykułów Modlitwy Pańskiej do Chrystusa Pana (k. 114r-120r), Pieśni nabożne z różnych miejsc Ewangelijej świętych ku chwale Bożej a zbudowaniu człowieka chrześcijańskiego złożone [...] roku Pańskiego 1678

2 Rycina ma dwie wersje: protestancką (Spirituale Christiani militis certamen z 1591) i jezuicką (Spiritale [!] Christiani militis certamen sprzed 1609) - por. ilustracja do niniejszej edycji. Praca ta musiała towarzyszyć Potockiemu przez całe życie, jej wpływ bowiem można dostrzec w dziełach powstałych w różnych dekadach: zarówno w debiutanckim Pojedynku rycerza chrześcijańskiego z lat czterdziestych, w Rozboju duchownym z przełomu lat sześćdziesiątych i siedemdziesiątych, jak i w Boju rycerza Chrystusowego powstałym w latach osiemdziesiątych XVII stulecia - zob. Grześkowiak, 2018, s. 226-241.

3 Imperatyw walki duchowej opisywali Ojcowie Kościoła, na ogół podając wrażą trójcę: Szatana, Świat i Ciało. Idea rycerza Chrystusowego została omówiona również w dziele Erazma z Rotterdamu Enchiridion militis Christiani. Potocki - za Wierixem - modyfikuje ów topos i przedstawia pięciu nieprzyjaciół metafizycznych.

4 Więcej na ten temat: Grześkowiak, 2018, s. 253-270.

5 Z jego dawnych okładzin wyjęto ponadto papierową makulaturę z łacińskim tekstem o sakramentach, pochodzącym $\mathrm{z}$ drugiej połowy XV wieku.

6 Aleksander Brückner spekulował, że poeta przekazał rękopis osobiście Andrzejowi Lubienieckiemu (Brückner, 1898, s. 294). W późniejszych latach manuskrypt trafił do Biblioteki Załuskich, a wraz z jej zbiorami - do Cesarskiej Biblioteki Publicznej w Petersburgu, i do Warszawy powrócił dopiero w ramach rewindykacji polskich zbiorów w latach dwudziestych XX wieku. W trakcie II wojny światowej rozpoczęto jego konserwację w pracowni Bonawentury Lenarta. 
(k. 121r-179v), Smutne zabawy żałosnego po utraconych dziatkach rodzica [...] w nadzieje powstania $z$ martwych i wiecznego żywota pochowanych (k. 188r-202r). Czystopis autografu Rozboju duchownego na drodze zbawiennej znajduje się w kodeksie na k. 180r-187v.

Do foliału skopiowano ponadto trzy utwory innych autorów: Kurant Jego Mości P[ana] podkomorzego kijowskiego [Stefana Niemirycza] samej Jej Mości [Gryzeldzie z Wylamów] złożony na nute francuska (inc.: „Sen mi każdej nocy / wystawia na oczy”, k. 202v), Pieśń P.P.A.A. złożo$n a$ (inc.: „Kiedy, smutni rodzicy, tak się Bogu zdało”, k. 203r) oraz średniowieczny hymn o inc.: „Cur mundus militat vana sub gloria” (k. 203v).

W tytułach skopiowanych utworów Potockiego pojawiają się kolejno cztery daty: 1679, 1678, 1673, 1677, teksty musiały więc zostać przepisane po 1679 roku, a przed 1696 rokiem, kiedy zmarł poeta.

Rozbój duchowny Potockiego wydano w 1980 roku (Malicki, 1980). Na naukowej wartości tej edycji cieniem kładą się stosunkowo liczne usterki, z których najważniejsze to:

1. niepełne odczytanie tekstu7;

2. błędne odczytania, zniekształcające tekst główny zarówno pod względem sensus, jak i metrum ${ }^{9}$;

3. usterki transkrypcji wyrazów w pozycji rymowej ${ }^{10}$;

4. lapsusy przy odczytaniu marginaliów ${ }^{11}$;

5. zaniechanie krytyki koniekturalnej przy edycji marginaliów ${ }^{12}$;

6. omyłki interpunkcyjne dowodzące niezrozumienia wydawanego tekstu' ${ }^{13}$.

Poprzednia edycja praktycznie pozbawiona była również komentarza rzeczowego, bez którego utwór Potockiego bywa dziś często niezrozumiały (nieliczne objaśnienia wydawcy, nie zawsze poprawne, skupiły się na kwestiach leksykalnych).

Wyliczone względy zadecydowały o potrzebie opracowania nowego, w pełni krytycznego i komentowanego, wydania poematu Potockiego. W niniejszej edycji tekst Rozboju duchownego

7 Wers 203, który w autografie Potockiego brzmi: „Pięć ich było, ilem mógł w onym baczyć huku”, w edycji Malickiego ma postać: „Pięć ich było [...], w ony barzy-ć huku”.

8 Np. „Chrystusa Pana” zamiast poprawnej lekcji „Chrysta Pana” (tytuł), „Ojcu swemu” zamiast „ojczystemu” (w. 14), „przyjmą” zamiast „przejmą” (w. 64), „użyć” zamiast „pożyć” (w. 79), „lecą” zamiast „leją” (w. 137), „z góry” zamiast „z buréj” (w. 137), „gorzkiego” zamiast „górskiego” (w. 147), „bezpieczniej” zamiast „bezpiecznie” (w. 192), „Jeśliż” zamiast „Jeślić” (w. 250), „nie przygasza” zamiast „Twych przygasza” (w. 318), „Ostając” zamiast „Ustając” (w. 420), „nużej” zamiast „mojej” (w. 498).

9 Np. „i którzy chęcią” zamiast lekcji autorskiej „którzy chęcią” (w. 63), „Z wielką niszczełe chęcią” zamiast „z wielką niszczeł chęcią" (w. 300).

${ }^{10}$ Np. „wprzódy - gody” zamiast „wprzody - gody” (w. 39-40), „ufortuni - ku niej” zamiast „ufortuni - ku niéj” (w. 95-96).

11 Np. „Gen. 27, 20” zamiast „Gen. 27, 28” (w. 46 marg.), „Joann. 2, 16” zamiast „1. Joh. 2, 16” (w. 215 marg.), „3. Reg. 14, 22” zamiast „3. Reg. 17, 22” (w. 389 marg.). Malicki nie weryfikował w swym komentarzu marginalnych odsyłaczy biblijnych, stąd ich brzmienie mogło być znacząco zniekształcone. Z tego samego względu część marginaliów została umieszczona w edycji przy innych wersach niż te, do których się odnoszą.

12 Np. błędny zapis podstawy wydania: „Num. 13, 14” (w. 119 marg.) w rzeczywistości odsyła do Lb 13, 24, „Num. 13, 14” (w. 163 marg.) do Lb 13, 34, „Matt. 7, 30” (w. 191 marg.) do Mt 7, 13, „2. Cor. 2, 6” (w. 386 marg.) do 2 Kor 3, 6, „Job 19, 34 " (w. 400 marg.) do J 19, 34.

13 Np. w w. 3-4, 19-20, 74, 77-78, 128-130, 167, 291, 297-298. 
oddawano po uwzględnieniu autopoprawek kopisty (wykreślenia oraz rozmazania atramentu, przerobione litery i słowa, nadpisane wersy, słowa i litery).

\section{Zasady transkrypcji}

W transkrypcji zastosowano współczesny system interpunkcyjny, a także obowiązującą dziś pisownię łączną i rozłączną oraz wielkich i małych liter.

Pochylone $a$ oraz pochylone $e$ oznaczono tylko w pozycjach rymowych (np. słomie - támie; szczyrze - zolniérze, ufortuni - ku niéj).

Zmodernizowano zapis samogłosek nosowych (np. dotad $\rightarrow$ dotą), m.in. nie honorując wtórnej nazalizacji (np. swęmu $\rightarrow$ swemu, miodęm $\rightarrow$ miodem) ani rozłożenia nosówki (np. Swięnty $\rightarrow$ święty, wygląndam $\rightarrow$ wyglądam). Wyjątek uczyniono jedynie dla dobrze udokumentowanych w barokowej polszczyźnie form tesknica i paszczeka.

Uwspółcześniono grafię $i, j, y$ (np. iakiey $\rightarrow$ jakiej, miia $\rightarrow$ mija).

Zmodernizowano pisownię $u, o$,ó (np. gorę $\rightarrow$ górę, pułtora $\rightarrow$ półtora), pozostawiając zapisy z o wówczas, gdy usprawiedliwia je etymologia wyrazów (np. pazory, Jakob, tłomoki, spłokana) lub pozycja rymowa (np. ogorki - dziorki, wprzody - gody, poty - niestoty).

Do postaci dzisiejszej doprowadzono pisownię szeregów $c, c ́ c, c z$ (np. miłowac $\rightarrow$ miłować, smierc $\rightarrow$ śmierć), a także $s, \dot{s}, s z$ oraz $z, \dot{z}, \dot{z}$ (np. Bose $\rightarrow$ Boże, Kuzni $\rightarrow$ kuźni, pomoß $\rightarrow$ pomóż, teß $\rightarrow$ też, zebym $\rightarrow \dot{z} e$ bym $)$.

Przyjęto obowiązującą dziś pisownię $h$, ch (np. herubinęm $\rightarrow$ cherubinem).

Zmodernizowano dźwięczność spółgłosek (np. hawty $\rightarrow$ hafty, Swiedzkie $\rightarrow$ świeckie, Scießka $\rightarrow$ ścieżka), wyjątek robiąc dla formy łabęci występującej w pozycji rymowej.

$\mathrm{W}$ wyrazach polskich obcego pochodzenia zmodernizowano zapis geminat (np. appetity $\rightarrow$ apetyty, okkazyiq $\rightarrow$ okazyja), pisownię $c$ oddawano jako $k$ (np. decret $\rightarrow$ dekret), ph jako $f$ (np. trymph $\rightarrow$ tryumf), qu jako $k w$ (np. quoty $\rightarrow$ kwoty), th jako $t$ (np. Threny $\rightarrow$ treny, Throny $\rightarrow$ trony), $x$ jako $g z$ (np. executiq $\rightarrow$ egzekucyja), a także oznaczono wzdłużenia (np. ambicyja, Ezechijasz), natomiast w łacińskich siglach zapis foddawano jako ph (np. Efes. $\rightarrow$ Ephes.).

Honorowano dawne końcówki czasowników czasu przeszłego -eł (np. poruczeł, wypełnieł), rzeczowników, przymiotników i zaimków w miejscowniku zakończonych na -em (jakiem, sprawiedliwem, w onem jabłku Ewinem), imiesłowów przysłówkowych uprzednich z końcówką -szy (rzekszy, nadszedszy) oraz rozkaźników (np. cofni, pojźry, westchni).

Ponieważ podstawą edycji był autograf Potockiego, nie ujednolicono oboczności: nagroda / nadgroda (i pochodne), egiptskie / egipskiej, w prefiksie stopnia najwyższego przymiotników i liczebników na-/naj- (np. największem, najpierwszy obok Naświętsze, namniej), a także formy autografu: $w$ czesie, niestoty, oczyściali, pojźrysz, pczoły, na szubieńcy.

\section{Wykaz skrótów oraz poprawek przyjętych w edycji}

Koniektury, polegające na zmianie lub dodaniu znaków, sygnalizowano w tekście utworu nawiasem kwadratowym (koniektury polegające na ujęciu znaków nie zostały oznaczone w transkrypcji, są jednak opisane w aparacie krytycznym). Wykaz poprawek i odmiennych rozwiązań 
transkrypcyjnych przyjętych w niniejszej edycji w stosunku do zapisu autografu: w. 13 [d]o złego (rkps: od złego), w. 31 czo[sn]ku (rkps: czonstku), w. 54 marg. [1.] Reg. 13, 19 (rkps: Reg. 13, 19), w. $57 \mathrm{~N}$ [i] e ma (rkps: Ne ma [w kustoszu lekcja poprawna: Nie ma]), w. 102 [ $\dot{z}]$ em (rkps: jem), w. 119 marg. Num. 13, [2]4 (rkps: Num. 13, 14), w. 132 przenoszace (rkps: przynoszace), w. 153 żadna (rkps: żadna), w. 162 marg. [4]. Reg. 19, 35 (rkps: 1. Reg. 19, 35), w. 163 marg. Num. 13, [3]4 (rkps: Num. 13, 14), w. 192 marg. Matt. 7, [1]3 (rkps: Matt. 7, 30), w. 219 łę[t] (rkps: łęk), w. 261 nadzi [ej]e (rkps: nadzię), w. 270 [z] swym (rkps: swym), w. 308 marg. Ibidem 20, [11] (rkps: Ibidem 20), w. 309 marg. Ibid. [20], 7 (rkps: Ibid. 7), w. 340 [z] zimna (rkps: zimna), w. 386 marg. 2. Cor. [3], 6 (rkps: 2. Cor. 2, 6), w. 400 marg. Jo[h]. 19, 34 (rkps: Job 19, 34), w. 406 j[u]sze (rkps: insze), w. 459 [z] Synem (rkps: Synem), w. 511 obdarż̇e m[ię] (rkps: obdarż̇e mnie) ${ }^{14}$.

Rozwiązanie siglów biblijnych z marginaliów utworu:

1. Joh. - Pierwszy List św. Jana

2. Cor. - Drugi List do Koryntian

1. Reg. - Pierwsza Księga Samuela

3. Reg. - Trzecia Księga Królewska (dziś: Pierwsza Księga Królewska)

4. Reg. - Czwarta Księga Królewska (dziś: Druga Księga Królewska)

Apoc. - Apokalipsa św. Jana

Ephes. - List do Efezjan

Exod. - Księga Wyjścia

Gen. - Księga Rodzaju

Joh. - Ewangelia według św. Jana

Jonae. - Księga Jonasza

Luc. - Ewangelia według św. Łukasza

Mar. - Ewangelia według św. Marka

Mat. / Matt. - Ewangelia według św. Mateusza

Num. - Księga Liczb

W objaśnieniach cytaty biblijne za: Biblia, to jest Księgi Starego i Nowego Testamentu..., tłum. J. Wujek, Kraków 1599. Skrótem NKPP oznaczono Nową księge przysłów i wyrażeń przysłowiowych polskich, t. 1-3, red. J. Krzyżanowski, Warszawa 1969-1972. Po skrócie podane są w cudzysłowie tytuły haseł, a po nich numery znaczeń.

\footnotetext{
14 Chciałabym podziękować prof. Radosławowi Grześkowiakowi za okazane wsparcie, wskazówki i przeprowadzenie mnie przez (niekoniecznie duchowe) zmagania z odczytaniem i objaśnianiem trudnego tekstu poematu. Wyrazy wdzięczności składam także dr. Dariuszowi Piotrowiakowi za cenne uzupełnienia i poprawki.
} 


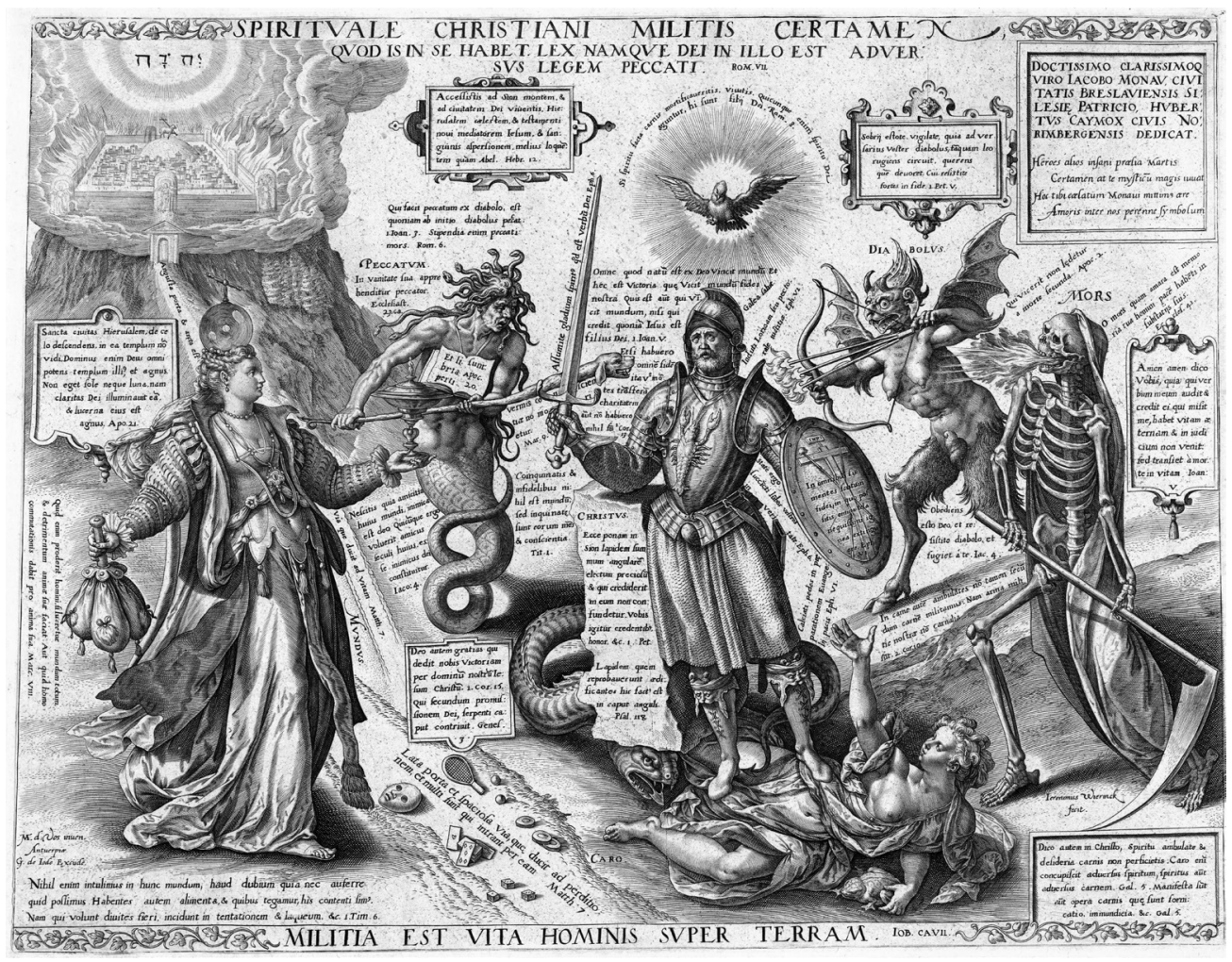

Hieronimus Wierix, Spirituale Christiani militis certamen, miedzioryt, przed 1591, $301 \times 398 \mathrm{~mm}$, Rijksprentenkabinet, Rijksmuseum, Amsterdam.

Źródło: Wikimedia Commons 
Rozbój duchowny na drodze zbawiennej, a przy tym wizerunk miłosierdzia Syna Bożego, Chrysta Pana, nad wszytkiemi grzesznemi ludźmi

Luc. 10, 30

Chcąc Bóg żydowską ująć zgraję onę sprzeczną,

Nie chlebną, ale miodną ziemię im i mleczną

Exod. 13, 5; Num. 13, 28

Obiecał (są na głupie dziecka różne środki:

Nie pomożeli im pręt, pomogą łakotki).

5 I chociaż nie przestali zwykłego narowu,

Zyścieł im k woli swemu obietnicy słowu:

Żeby im z głowy wybieł egiptskie ogorki,

Nalał mlekiem i miodem aż po same dziorki

Wszytkich zgoła rozkoszy, co się ciała tyczą,

Napełnieł Jeruzalem, ich miasto, słodyczą.

Półtora tysiąca lat, ledwie włócząc brzuchy,

Tyli jak wieprze w sadzu, jak w maśle pampuchy,

Choć ustawnie [d]o złego wracając nałogu,

Bałwany czczą, uwłocząc ojczystemu Bogu.

15 I już by byli z ludzkiej zmazani pamięci,

Ale bronieł Abraham przycisnąć pieczęci

Na dekret po tysiąckroć w sprawiedliwem gniewie

Ferowany, jakiem ich na puszczy przeplewie,

Kędy Żydów ogniste zabijały węże.

20 Więc kiedy już mogli być z niemowiątek męże

(Dosyć dwa tysiąca lat w rozum rość na człeka),

Mogli też już od manny, od miodu, od mleka

Dziecińskie podniebienie obrócić do chleba,

Co trwalszy żywot daje, więc Go spuści z nieba.

25 Spuści im Bóg posilny i on chleb tak syty,

Który nie tylko wszelkie śmierzy apetyty,

Ale strucie, co na śmierć wieczną nas kaleczy

W onem jabłku Ewinem, swojem smakiem leczy.

Trudno z błaznem na ryby, bo nie chce do wody:

30 Znowu Żydzi do dawnej wracają się mody,

Bo ledwie od ogórków, czo[sn]ku i cebule

Na pełne młosty mleka, pełne miodu ule,

Chociaż z ciężkiej niewoli egipskiej, wżdy z żalem

I z okrutną tesknicą szli do Jeruzalem.

35 Kędy skoro już miodu skosztowała mucha,

Niech do nich sam Abraham przyjdzie, nie usłucha. 
Niechaj niebo zaleca, a piekłem ich straszy,

Mleka Żydzi i miodu, zwyczajonej paszy,

Nie puszczą się do zdechu, pomrzeć wolą wprzody,

40 Niżli na chleb i wieczne Bogu stawić gody.

A widziszże, Jakobie, coś za kęs polewki

Gen. 25, 33

Otrzymał u Ezawa pierworodne wlewki,

Oto dziś twoje plemię za mleczko, za miodek

Żydzi poganom zbawienie

Puszcza cug Ezawowi i do nieba przodek.

45 Kiedyć błogosławieństwo ociec dawał Boże,

Tłustą na świecie rolą, olej, wino, zboże,

Gen. 27, 28

Dał ci górę nad bratem i niskoć się kłaniał,

Skoroś go z ziemie i z miast jego powyganiał.

Gen. 36

Półtora tysiąca lat bez mała, nie dłużéj,

50 Jako potomstwo twemu Ezawowe służy,

Aleć i temu ociec hojnie błogosławi,

Dawszy pług Jakobowi, jemu miecz zostawi.

Gen. 27, 40

I był czas, że Izrael we wszytko bogaty,

Nie miecza, lecz kowanej nie mógł mieć łopaty,

[1.] Reg. 13, 19

55 Nie mający kowala (gdy siedział na tronie

Saul, musieli prosić Filistynów o nie).

$\mathrm{N}$ [i]e ma krzywdy, darmo się biedny Ezaw smuci,

Przyjdzie ten czas, że jarzmo Jakobowe zrzuci,

Bo mu to Izak przydał, a co dotąd panem,

60 Będzie też Ezawowi, Jakob zaś poddanem.

Dla Boga, azaż się to jawnie dziś nie iści?

Azaż Żydzi nie wszytkim poganom w korzyści?

Ale tam naprzód, którzy chęcią tu uprzejmą

Pogardzonego od nich Mesyjasza przejmą.

65 Nie tylko w pierworodztwie rzecz skazuje sama,

Ale ich i w synowstwie ojca Abrahama

Uprzedzą, po Ezawie wziąwszy i Jakobie

Błogosławieństwa Boże, miecz i lemiesz obie.

Cóż nam ten świat, który tak wszyscy sobie chwalem?

70 To wprawdzie to, co było Żydom Jeruzalem.

Co są wszytkie pociechy, rozkoszy, wygody,

Pompy, sława, bogactwa? Tylko mleka, miody,

Których ledwie ze łzami liźniemy na poły,

Aż my umieramy (wnet i krowy, i pczoły).

75 Chleba nie pytaj, chociaż tak twierdzą doktorzy,

Że bez niego i mleka, i miód brzuchy morzy. 
Jest ci chleb żyzny, trwały, smaczny, a cóż po niem,

Kiedy wołem ani nań nie zaorzesz koniem?

Duszę trzeba i ciało, chceli go kto pożyć,

80 Do jarzma miasto konia, miasto wołu włożyć.

Dlaczegóż, przebóg, płacze, dlaczegóż narzeka,

Idąc na chlebne gody człek od tego mleka?

Luc. 14, 15

Nalazłbyś tak głupiego ludzi apetytu,

Którzy odstąpią nieba dla ziemskiego bytu.

85 Świadkiem są tak żałosne z świata przenosiny,

Jako nam ciężkie w serca świat zabija kliny.

Lecz że fortą do nieba, musi się w niej schylić,

Kto tam zmierza. Przestrzegam: waruj się omylić.

Byłem i ja tak głupi w mojem wieku młodem:

90 Mlekiem się i doczesnem nasycając miodem,

Kochałem Jeruzalem ziemskie tak dalece,

Żem w nim wszytkie pokładał swoje kontentece.

Rozumiałem, że wiecznem prawem w nim dziedziczę

Wczas i dobry byt ciała, a co pierwszą liczę -

95 Wielką $\mathrm{z}$ dziatek pociechę, gdzie mię ufortuni

Bóg mój nad wszelką godność. Przystępuje ku niéj

Ambicyja honorów - acz jest inszym płochą,

Nie stawiła mi się ta fortuna macochą.

Nie myśliłem jak żywo o czym lepszem, alem

100 Wszytkom szczęście w tym ziemskiem liczeł Jeruzalem,

Kędy nie czując żadnych w sercu swoim moli,

Nie czułem, choć prawdziwie, w tej [ż]em był niewoli.

Umiałeś w to potrafiać, umiał mi to zganić:

Wszytkie świeckie przysmaki zebrawszy jak na nić,

105 Uciąłeś, mocny Boże, odjąwszy mi dzieci,

Aż, co miał zdobić, honor, starość moję szpeci.

Aż mię zdrowie odbiega, bo wiem, kto się smęci,

Nie rozweselą skrzypce ani go łabęci

Mech uśpi, ani przysmak, ani trunek, ani

110 Przyjaciel go ucieszy mową. Wszytko gani,

Wszytko mu nie do myśli, wszytko zgoła krzywo,

Co przedtym było miłe. Żyć mu nawet ckliwo.

A toż mleczko, a toż miód. Tak żem był oszalał,

Zakochawszy się w świecie, aż skorom go zalał

115 Serdecznych łez rosołem, zostawszy sierotą,

Dziś się nim dopiero klnę, dopiero z ochotą 
Z tego się Jeruzalem, kędy człowiek wzdycha

Na ciężkie szkody, kwapię do Twego Jerycha,

Gdzie nie grona, lecz serca tych, co drogą prostą

Num. 13, [2]4

120 Chodzą przed Tobą, w słodkie jagody wyrostą,

Które żadnej odmiany niewyżęte prasą,

Na wieki nieskończone Twoich świętych pasą;

Gdzie nie miód i nie mleko, które namniej duszy

Nie da posiłku, ciało do godziny puszy

125 (Prawdziwieć tylko puszy, bo skoro śmierć trzęśnie,

Aż ona sroga bania w szczyptę prochu sklęśnie,

Ale ona, co wszelką bujnością swą ziemię

Przechodzi, złota skiba, wracając na siemię

Cnót i dobrych uczynków, kto go siał w tym wieku,

130 Chleb syty, chleb anielski przynosi człowieku);

Gdzie żywe źródła, smakiem i mleka, i miody

Doczesne przenoszące, onej płyną wody,

Która na wieki słodkiem chwały Twojej pieniem,

Wielki Boże, z ust świętych wypłynieć strumieniem;

135 Gdzie rozkosz bez bojaźni, gdzie wszelkiej pieszczoty

W królestwie Twoim nie ma-ż liczby, nie ma-ż kwoty,

Nie leją deszcze, nie dmą wiatry, ani z buréj

Głosem strasznego grzmotu grozi piorun chmury,

Lecz wieczna bez obłoków pogoda i cieni,

140 Bo nigdy nie zachodząc, niebo Twe rumieni

Wieczne słońce. A cóż tam po słonecznem świetle,

Gdzie blask Twojej stolice, przed którym w pomietle

Słońce świata być musi, promień ciska jary

Na niepojęte myślą Twoich państw obszary?

145 Tam, tam, o dobry Boże, z serdecznych łez pluty,

Z tego świata, gdzie mlekiem macierzystem struty,

Co dzień śmierci wyglądam, gdzie górskiego miodu

Żaden człowiek nie liźnie bez żądła, bez wrzodu,

Tam bieżę, tam się kwapię, gdzie mię wieczny z chlebem

150 Żywot czeka. Daj mi być odważnym Kalebem,

Num. 13, 31

Choć mię wszytkie afekty, wszytkie zmysły straszą,

Stawiając mi trudności, wiarę we mnie gaszą.

Naprzód wysokość nieba - żadną z ziemie posztą

Ani rozumem, ani myślą ludzką dosztą,

155 Cóż mówić o źrenicy śmiertelnego oka.

Tegoli ciało może dostąpić wysoka? 
A potym, możnali rzecz, tam się zmieścić w ciele,

Gdzie sami tylko święci, gdzie obywatele

Przejdą wzrostem obrzymów, jedną bowiem nogą

160 Na pół ziemie, drugą stać na pół morza mogą,

Apoc. 10, 2

Bo sto ośmdziesiąt i pięć, kiedyś się użalił

Miasta swego, jeden z nich, tysięcy, powalił?

Szarańczą stosowany człowiek jest $\mathrm{z}$ aniołem,

Jakoż tedy z nim w niebie może mieszkać społem?

[4]. Reg. 19, 35

Num. 13, [3]4

165 Tak się widzi rozumu człowieczego biegiem,

Ale Jozue, który stamtąd przyszedł szpiegiem,

Jozue, mówię, wtóry - Jezus, Syn Twój drogi

Z wysokiego Jerycha na ziemskie podłogi,

Ten świadczy (a wierzyć mu koniecznie się godzi,

170 Bo nie tylko, że się w nim przed wieki urodzi,

Ale utwierdzając swe świadectwo w zakładzie,

Na przeklętem krzyżowem drzewie duszę kładzie),

Ten świadczy, że każdy człek, co przestrzega cnoty,

Opuściwszy ten obóz i wszelkie namioty,

175 To ciało, gdzie gorzej niż w płóciennej kotarze

Siedzi wspaniała dusza jako ptak na szparze,

Wyglądając, rychło z nią Śmierć pociągnie nitki,

Że wzleciawszy, niewczesne opuści przybytki,

Ciało, mówię, śmiertelne, kto chce tylko szczyrze

180 Między Jego odważne pisać się żołniérze,

W toż wstępując z Jozuem i z Kalebem strzemię,

Świętą onę i świetną odziedziczy ziemię.

Tędyć i ja, kinąwszy wszelakie postrachy,

W niebieskiego Jerycha pobieram się gmachy

185 Z ziemskiego Jeruzalem, $\mathrm{z}$ dzisiejszem podróżnem,

Lecz nie tak, jako w drodze, trzeba być ostrożnem.

Idę drzymiąc, nikczemna myśl mnie ubezpiecza,

Nie śni mi się o zdradzie. Ni tarcze, ni miecza,

Bo acz było oboje, ale miasto boku,

Ephes. 6, 16

190 Nie bez wielkiego wstydu wyznaję, w tłomoku.

Nie miała miejsca u mnie zbawienna przestroga:

Idę bezpiecznie, gdzie mię bita wiedzie droga,

Mat. 7, [1]3

Chybiwszy wąskiej, przykrej, przez ciernie, przez osty,

Ale bezpiecznej, ale ścieżki barzo prostéj.

195 Dopiero błąd obaczę, kiedy mu już żadną

Miarą nie ujdę, kiedy łotrzy na mnie spadną. 
Pełno koło mnie ostrych mieczów, pełno grotów,

Uciec rzecz niepodobna, bronić się niegotów,

Wyprosić nie pomyślać, bo wzrok ich ponury

200 Owe srogie rozjadłe wyraża jaszczury,

Sępy albo okrutne harpije, co szczyrem

Serc ludzkich, inszą gardząc zobią, żyją żérem.

Pięć ich było, ilem mógł w onym baczyć huku.

Szatan najpierwszy na mnie porwał się do łuku,

205 Jego bełty ogniste, z żył ludzkich cięciwy,

Ephes. 6, 16

Trucizną zaprawione, płomień sypią żywy.

Drugi łotr Grzech, ten węża rajskiego kibici,

Gen. 3, 1

Serca się zaraz mego i sumnienia chwyci

Oną sprosną paszczeką, skąd miasto języka

210 Tysiącem jadowitych żądeł na mię kszyka.

Trzeci Śmierć, ledwie oczy od ziemie podniosę,

Apoc. 6, 8

Widzę, ach, widzę strasznie wyniesioną kosę,

Z której ciepła jeszcze krew moich wdzięcznych dzieci

Siarczystemi kroplami na serce mi leci!

215 Czwarty nieprzyjaciel Świat, ten w panieńskiem stroju, 1. Joh. 2,16

W jednej pełen trzos złota, w drugiej kusz napoju

Apoc. 17, 4

Trzymając ręce, tym mnie raczy podarunkiem,

Chcąc usidlić bogactwem, chcąc upoić trunkiem.

Piąte, własne me Ciało, żem jako łę[t] goły

Matt. 10, 8

220 Z duszą został, sprzysięgło się z nieprzyjacioły.

„Możeż być większa zdrada i większa niecnota

Od mego chlebojedźce - zawołam - jako ta?”

Lecz próżna moja skarga, próżne były treny.

Słuchasz, jakie skończenie tak żałosnej sceny?

225 Odarli mnie do naga i co gotowizny

Było, wzięli, zadawszy rany mi i blizny

Luc. 10, 30

Suchych razów. Odeszli. Ostatek krwie ciecze.

Leżę, czekając, rychło z drogi kto zewlecze

I ruszony niewczesnej miłosierdziem chuci,

230 Jeszcze w poły żywego gałęziem przyrzuci,

Miasto barwierza, miasto srogich ran zawoju.

Leżę w tak opłakanym dusze mej rozboju,

Leżę w serdecznem bólu, leżę w strachu, który

Wszytko złe przenosi, ból i strach śmierci wtóréj.

235 Źlem rzekł, nie śmierci wtórej, z dusznego rozbicia,

I ból, i strach wtórego przenosi ożycia. 
Leżę, nie ma-ż zdrowego członka na mej duszy,

Zleciał się już do ścierwu wszelki rodzaj muszy

I jeśli się jeszcze krwie kropla jaka warta,

240 Wyssie ją z niej gadzina przeklętego Czarta.

Nie muchy, już piekielni zalatują sępi,

Czekając, rychłoli mnie Stworzyciel potępi,

Rychłoli mnie, nędznego, śmierci odda wtoréj,

Gotowi będąc we mnie utopić pazory.

245 Leżę, Bóg mi wysoko, przyjaciel daleko,

Jużże Jego zapadło miłosierdzia wieko.

Ej, duszo, nie rozpaczaj: w nadziei żywota

Słychiwałem czyniących na szubieńcy wota

I nie były daremne! Nie rozpaczaj, kto wie,

250 Jeślić się utracone nie przywróci zdrowie.

Nadzieją wszyscy stojem, pierwszą zaraz bierze

$\mathrm{U}$ niepewnej fortuny nadzieja przy wierze,

Nadzieja nam z oddechem w miękkie wchodzi płuca.

Nikogo tak na świecie fortuna nie rzuca,

255 Żeby mu i największem okrucieństwem z garła,

Póki dechu nie wydrze, nadzieję wydarła.

To fortuna, którą człek wiatrem nazwać może,

Jakoż daleko więcej miłosierdzie Boże

Przeciw swemu stworzeniu, gdzie szczęście przytaczać

260 Za srogi grzech poczytam, nie da mi rozpaczać.

Kto weń wierzy, kto całą w Nim nadzi[ej]ę kładzie,

Kto szczyrze grzech porzuci i na tym Bieszczadzie,

Choć ranny, choć śmiertelnie obnażony, leży,

Pośle mu cyrulika, pośle mu odzieży.

265 Więc, dusza ze wszytkich cnót od Czarta rozbita,

Jeśli człowiek tonący i brzytwy się chwyta,

Chociaż wie, że się urznie, chwytaj się opoki

Miłosierdzia Boskiego, westchni, westchni wskoki.

Żałuj za grzech i odwróć od niego się szczyrze,

270 Uczyń ślub, uczyń wieczne [z] swym Stwórcą przymiérze,

Że będziesz ostrożniejszy na zbawiennej drodze,

Że przybierzesz narowom Ciała swego wodze,

Że cię do nieba ciasna poprowadzi ścieżka,

Że nie weźmiesz od Świata wina ani mieszka

275 (A jeśli też które $\mathrm{z}$ tych przed tobą położy,

Że na zbawienie sobie i ku chwale Bożéj 
Obrócisz to oboje, bogactwa i sławę),

Że Grzech i wszelką jego porzucisz zabawę,

Żeć w myśli nie postoi, że Boską obrazą

280 Brzydzić się wiecznie będziesz, nie uderzysz płazą

Na wszelakie zgorszenie, gdzie przestrzegać lepiéj,

Że cię żaden wzgląd, żaden respekt nie zalepi,

Że Szatan w sercu twoim, kędy rad uprzędzie

Za lada okazyją, miejsca mieć nie będzie,

285 Że mu przyjaźń wypowiesz (niech straszy, niech strzela,

Jeśli Bóg nie pozwoli, nie trafi do cela),

Żeć Śmierć nie będzie nigdy tak dalece sroga,

Żebyś obrazić albo odstąpić miał Boga,

Że jej wszytkie, choć ciężkie, zaboje w swym domu

290 Skromnie ponosić będziesz. Bóg bowiem nikomu

Nie czyni krzywdy: choć nas ckliwo, choć nas boli,

Co dał, wolno mu znowu wziąć wedle swej woli,

A kto na Jego razy niecierpliwie biada,

Taki Mu posłuszeństwo winne wypowiada.

295 O Boże mój, w którego miłosierdziu żadna

Nie znajdzie się odmiana, nie ma dna, nie ma dna

Morze dobroci Twojej: w obietnicach wierny,

W karaniu zaś leniwy albo miłosierny.

Wieleś razy dekret swój, choć już pod pieczęcią,

300 Wydany na człowieka z wielką niszczeł chęcią,

Jeśli płakał i łzami twarz przed Tobą zlewał.

O co się niegdy Jonasz tak barzo rozgniewał,

Jonae. 4,1

Widząc, że Niniwitów swe proroctwo chybi,

Chce utonąć, ale mu bronią wielorybi.

305 Już był na śmierć osądzon Ezechijasz wrzodem,

4. Reg. 20,2

Ledwie zapłakał, zaraz szedł dekret odwodem,

Ażeby temu wierzył: już minąwszy za się,

Wrócieł przez dziesięć linij wzad cień na kompasie.

Ledwie mu prorok figę przyłoży do wrzodu,

Ibidem 20, [11]

Ibid. [20], 7

310 Aż on zdrów do kościoła idzie dla obchodu.

Oto ja, miłosierny Boże, nie na łożu,

Ale leżę w bezludnem polu na rozdrożu:

Gdzie pojźrysz, wszędzie wrzody i śmiertelne pryszcze.

Szatan patrzy, rychłoli moję duszę zyszcze,

315 Którą skoro z uczynków dobrych cale złupi,

Brzydkich grzechów kancerem niestotyż zastrupi. 
Pojźry na mnie tak, jakoś na Ezechijasza

Pojźrał, a niechaj mój płacz sądów Twych przygasza.

Ulecz mię, złożonego śmiertelną chorobą,

320 Prawdać, że ja nie mam co, jako on przed Tobą,

Z dobrych liczyć uczynków. Wyznaję po prostu,

Że we mnie nic dobrego od pierwszego wzrostu

Nie było i dziś nie ma-ż, ale pewnie będzie,

Jeśli mi w tej chorobie słońce nie zasiędzie.

325 Pozwólże mi na świecie do pokuty czasu,

Cofni jeszcze nazad cień dni moich kompasu,

Które bieżą do końca $\mathrm{z}$ wiatrem na wyścigi.

Przyłóż na mą morówkę soku z onej figi,

Która, wisząc żałośnie nad krzyżowem klocem,

330 Całemu światu zdrowem kwitnęła owocem.

Pojźry na płacz mój, który w serdecznych łez zbiórce

Leję do Ciebie, Boga i mojego Stwórcę.

Ciebieli, któryś wodą świat zalewał, Boże,

Pokutnej łzy wylana kropla ruszyć może.

335 Niechże Cię ruszy, proszę, żebyś jeszcze nie tu

Czynieł egzekucyją swojego dekretu.

$\mathrm{W}$ tak opłakanem razie, $\mathrm{w}$ tak mizernej doli

Jednając się z swym Panem, wyglądam, rychłoli

Nadszedszy, użali się, a z tego pogromu,

$340 \mathrm{Z}$ deszcza, [z] zimna, $\mathrm{z}$ niewczasu, weźmie kto do domu.

Aż kapłan przeciwko mnie tąż się drogą spieszy.

Duch w mię wstąpił i serce nadzieją pocieszy:

Inszych ćwicząc w duchownej miłosierdzia szkole,

Będzie sam miał nade mną pokazać go pole

345 (Nie tak ludziom nauki w posłuch idą rady,

Jako w mistrzach przystojnych uczynków przykłady).

Ledwieże pojźrał na mnie, nie rzekszy nic, minął.

Westchnę ciężko ku niebu: „Ach, jużem też zginął!”.

Chcę rzec: „Ojcze”, ale mi w pół nie stało pary.

350 Bóg mówi: „Miłosierdzia chcę, a nie ofiary”.

Ledwie ten z oczu zginie, aż idzie lewita -

Nie kapłan, ale księgi Zakonu też czyta.

„Trzeba by tu barbierza” - patrząc na mię, rzecze.

Tyleż łaski, bo rzekszy, w swą się drogę wlecze.

355 Albo strach zdjął obudwu z mojego przykładu, Albo im też żal było prace i nakładu. 
„Jużci mi być - pomyślę - wiecznej śmierci łupem.

Kiedy się nie zmiłował lewita $z$ biskupem,

Po kiemże miłosierdzia spodziewać się, po kiem?”.

360 To gdy myślę, aż jedzie Samarytan bokiem.

Cóż po tym? Jeśliż kapłan i lewita minie,

Pewnieć ten cudzoziemiec ran mych nie zawinie.

Aleć ten, obaczywszy srogie moje cięcia,

Skoczy, na którym siedział, z swojego bydlęcia,

365 Dobywszy flaszę z winem, a z oliwą drugiéj.

Lepszej po cyruliku nie będzie wysługi:

Winem rany wymywa, toż oliwą tłustą

Napuściwszy, rozdartą zawija je chustą.

Potym, sam idąc pieszo, na swe bydlę wsadzi

370 I nazad mię po lekku do miasta prowadzi.

Tam sam ze mną w najętej nocuje gospodzie,

O wszelkiem wczasie mojem radząc i wygodzie.

Nazajutrz, wyjąwszy dwa srebrne z mieszka grosze:

„Weźm - rzecze - gospodarzu, a przy tym cię proszę,

375 Ja odjeżdżam, miej o tym człeku pilną pieczą,

Którego wczora łotrzy na drodze skaleczą.

Wracając się, wydaszli więcej na barwierza,

Z osobna za staranie oddam do halerza”.

Któż tak miłosiernego wizerunkiem czynu?

380 O Jezu, nieodrodny Ojca swego Synu,

O mój Samarytanie, o dobroci sama,

Tyś mnie nadszedł, potomka przeklętego Chama,

Którego jeszcze w raju, skoro się oblecze

Szatan w łupież wężowy, odrze i posiecze.

385 Mija kapłan, i słusznie, lewita mię mija,

Bowiem starozakonna litera zabija.

2. Cor. [3], 6

Miasto jakiej pomocy, kto sam także nagi,

Kto na duszy z rozbitem, jedneż cierpi plagi.

Niechaj będzie Elijasz, co umarłych wskrzesza,

390 Niechaj sobie na pomoc przybierze Mojżesza,

Niech się wszyscy prorocy zbiorą z swymi dziwy,

Cóż po tym, kiedy nie ma-ż wina i oliwy?

Obojeś to, o Jezu, przyniósł na świat ranniéj.

Stały pełne przed Tobą wina $\mathrm{z}$ wody wanny,

395 W których się dotąd Żydzi oczyściali z brudu Joh. 2, 6

Ten był początek Twego w Galilejej cudu. 
Lecz nie to wino, nie to, które ludzi poi,

Mnie i wszytkich rozbitów mnie podobnych goi,

Lecz ono wino z wody, co krynicą żywą

400 Wypłynęło na krzyżu z Twojej krwie oliwą.

Jo[h]. 19, 34

Tą wodą po krzcie świętem śmiertelnej nas skazy,

Mar. 16, 16

Tą ognia piekielnego oliwą zarazy

Joh. 6, 53

Zachowujesz przy swojej Naświętszej Ofierze,

Gdzie wino krwie niewinnej substancyją bierze.

405 Niechajże u starego swe Żydy ołtarza

W bydlęcej j[u]sze Mojżesz i z głowami narza

Na śmiertelne zranienie - że podła, że tania,

I marli bez nadzieje, i mrą, zmartwychwstania,

Ale krew Twoja, która świat z Bogiem przymierzy,

410 Nie docześnie karanie tylko za grzech śmierzy,

Lecz że droższa nad wszytkie bydła, srebra, złota,

Otwiera Twym wyznańcom $z$ grobu w niebo wrota.

Dałeś z siebie i chusty, dałeś szatę zdzierać,

Żebyś zawinąć, żebyś miał czym i ocierać.

415 O żałosne flejtuchy na mej dusze rany,

Stałeś nagi jak palec, żebym był odziany!

Zsiadłeś z konia, o Jezu, na tę niską ziemię,

Wziąłeś napchane grzechem dusze mojej brzemię,

Dźwigałeś go trzydzieści i pół czwarta roków,

420 Ustając pod tak sprosnych ciężarem tłomoków,

Chcąc mnie wsadzić na tego, z któregoś zsiadł, konia,

Sam idąc pieszo, Jezu (niezbrodzona tonia

Miłosierdzia rozumem ani myślą człeczą),

Podjąwszy dla robaka swego taką pieczą.

425 Zsiadł Samarytan z konia, a Ty z nieba, Panie,

Żebyś mnie (a cóżem ja?) z ziemie wsadzieł na nie.

Znalazłeś mi gospodę w tego świata mieście,

Nająłeś gospodarza, który swe obeście

I wszelki ma dostatek, gdzie nie tylko leki

430 Z niebieskiej na me rany wychodzą apteki,

Ale za delikackiem zawsze siedzę stołem

Twym, a to ten gospodarz świętym jest Kościołem.

Nie trzeba mi lepszego ojca ani matki,

Wszelkie mam w nim wygody i wszelkie dostatki.

435 Jemuś mnie Ty zleciwszy, na głowie do włosa

Poruczeł i dobywszy jeszcze nadto $\mathrm{z}$ trzosa 
Dwu groszy, dałeś mu je, obiecując, skoro

Nazad wrócisz, nagrodzić pracą w dziesięcioro.

O szczęśliwy na rany i na moje blizny

440 Wielkiej i niepojętej zadatek iścizny,

Którym Kościół doczesne swoje sakramenty

Aż do Twego powrotu szafuje Duch Święty.

Jezu, któryś tak wielki koszt mnie k woli łożeł,

Żeś się sam, Bogiem bywszy, aż na śmierć zubożeł,

445 Bądź pochwalon na wieki nieskończone, a tu

Niech będzie jawne Twoje miłosierdzie światu,

Żeś mnie, com już na drodze trupem gnieł w kolei,

Podźwignął ku wiecznego żywota nadziei

Krwie, której kropla ceną świat przeniesie mytem.

450 Pokazał Samarytan litość nad rozbitem

I patrząc na staranie, a na jego koszty,

Zda się, że nader człeku wielką, ale złoż Ty

Prace, roboty, której bóstwo nie przywyknie,

Męki swoje, śmierć swoję, ale - przebóg - zniknie,

455 Zniknie, ani się nazwać miłosierdziem godzi

Uczynności, którą człek człeku zaś nadgrodzi.

Ciebie co za nadgroda, co za wdzięczność czeka

Śmierci krzyżowej, tylko żebyś widział człeka

W niebie królującego Ojca swego [z] Synem,

460 Żebyś $\mathrm{z}$ Duchem, żebyś go równał $\mathrm{z}$ cherubinem.

Nieprzyjaciela swego, trudno go zwać człekiem,

Co mało na trzech onych mając, nowym ćwiekiem

Serce Twoje z szatańskiej katuje przynuki,

Choć nań co dzień śmiertelnych strzał wyciąga łuki.

465 Ta Cię potka nagroda za Twe krwawe poty,

O Jezu, Synu Boży, ta wdzięczność, niestoty.

Zmiłujże się nade mną, bo to mało jeszcze,

Że się z wiernymi Twymi w tej gospodzie zmieszczę,

Że Cię znam swym lekarzem, że już moja rana

470 Na krzcie wodą w kościele, Twoją krwią spłokana,

Jeśli coraz w nadzieję takiego omycia

Będę chcący przychodzieł diabłu do rozbicia.

Choć często upomina, choć gospodarz radzi,

Boję się, że mnie kiedy razem wyprowadzi

475 Z tak wygodnej Kościoła Twojego gospody

Do piekarnie, gdzie same śmieci, same smrody, 
Że coraz oświeżając gojące się rany,

Nigdy ich nie zagoję. Nuż niespodziewany

Powrócisz, cóż za korzyść mojego niestatku?

480 Upomnisz się, upomnisz swojego zadatku,

Który w wielki kapitał urośnie tymczasem,

Upomnisz się swych kosztów, karb zaraz za pasem,

Będzie świadczeł gospodarz. Jam kaleka goły,

Płacić trudno, żebyś mi nie kazał do smoły,

485 Gdym na świecie nie umiał szanować oliwy.

Więc do końca, o Jezu, pokaż, dobrotliwy,

Miłosierdzie nade mną, niech z tych groszów pary

$\mathrm{Na}$ oczy serca mego sprawię okulary,

Żebym śmierć, żebym żywot, żebym widział w czesie

490 Krótką doczesność, wieczność bez końca i gdzie się

Pobierać z tego świata, doskonałość rzeczy

Niebieskich, marność ziemskich, którymi kaleczy

Szatan człeka w tej drodze, że co się wyliże,

Tymże go zaraz grzechem rani, tymże strzyże.

495 Psują plastry barwierze, nie chcą się jąć hafty

Owrzedziałego w człeku sumnienia, potraf Ty,

Jezu, mędrszy nad wszytkie Eskulapijusze,

Potraf, lekarzu wieczny, w defekt mojej dusze:

Strzyż złe mięso, nim ogień piekielny się wkradnie,

500 Choć się ten szkapa wierci, trzymaj palec w sadnie.

Pomóż mi na skażoną swych groszów naturę

Przeciwko Szatanowi kupić armaturę.

Żeby i on, i jego bała się mnie orda,

Trzeba obosiecznego Twego Słowa korda.

505 Niechaj Twe obietnice, Twe straszliwe grozy

Ephes. 6, 15-16 etc.

Między Twych kawalerów wpiszą mnie obozy.

Ażeby mi na drodze smok ten nie zasiadał,

Tarczę na jego strzały, którą bym się składał,

Trzeba, którą Abraham ukazuje stary,

510 Że nigdy być nie może lepsza jako $\mathrm{z}$ wiary.

Choćbym gór nie przenosieł, Panie, obdarzże m[ię]

Wiarą, żebym nią w niebo siebie przeniósł z ziemie.

Potrzebny w okazyjej i szyszak codzienny,

Nie ma-ż jako ze spiże nadzieje zbawiennéj,

515 Wszytkie kule i świata tego zawieruchy

O ten się jako o dzwon rozbijają muchy, 
O ten, choć nic bystrszego nie ma-ż, równa słomie

Ostra się nieużytej Śmierci kosa łámie.

Blachu trzeba, który by pierś śmiertelną szczyciéł,

520 Żeby się nigdy brzydki Grzech serca nie chwycił -

Miłość jest przeciw Bogu, bliźniemu i sobie,

Upewniam, że jej ten wąż żądłem nie przeskrobie.

Jestże Cię zacz miłować, o mój Jezu drogi,

Daj tylko swej miłości, mym piersiom załogi,

525 Gdy rąk i nóg ucinać, oczu nie chcą łupić,

Pomóż na wszytko ciało mocny pancerz kupić

Świętej sprawiedliwości, żebym naprzód Tobie,

Co należy, też ludziom oddawał i sobie;

Żebym tak prawdy swojej przepasany sznurem

530 Stał na wszytkie cielesne poczciwości murem.

Więc gdy zawsze trzeba być gotowem ku bitwie

Nie drzymiąc, w ustawicznej daj mi strzec modlitwie:

„O, któryś zginionemu światu na ratunek

Z nieba zstąpieł, gdzie taki rodzi się rynsztunek,

535 Synu Boga żywego, wodzu świętej wiary,

Opatrz i mnie na wszytkie szatańskie poczwary

(W który komput i moje własne Ciało wchodzi)

Orężem, jakie w kuźni niebieskiej się rodzi.

Odziej nienaruszonem wszytkich nas kirysem,

540 Żebym, gdy przyjdziesz na świat ostatniem popisem,

Onę sławę, co w niebie nigdy nie umiera,

I tryumf nieśmiertelny odniósł z tego zbiera”.

\section{Objaśnienia}

w. $1 \quad \dot{z} y d o w s k a ̨$ ująć zgraję onę sprzeczna - tj. pozyskać skłócony naród żydowski.

w. 2 marg. Por.: „A gdy cię wprowadzi Pan do ziemie Chananejczyka i Hetejczyka, i Amorejczyka, i Hewejczyka i Jebuzejczyka, którą przysiągł ojcom twoim, że być ją dał, ziemię płynącą mlekiem i miodem, będziesz obchodzić ten obyczaj obrzędów miesiąca tego” (Wj 13, 5), oraz: „Przyszliśmy do ziemie, do którejś nas posłał, która zaiste opływa mlekiem i miodem" (Lb 13, 28b).

w. 2-3 Nie chlebną, ale miodną ziemię im i mleczną / Obiecał - tj. Bóg obiecał Żydom ziemię nie tylko urodzajną, lecz wręcz miodem i mlekiem płynącą; por: „Ziemia, którąśmy obeszli, barzo dobra jest. Będzieli nam Pan miłościw, 
wprowadzi nas do niej i da nam ziemię mlekiem i miodem płynącą" (Lb 14, 7b-8).

w. 4 Nie pomożeli im pręt, pomoga łakotki - tj., jeśli nie pomoże karanie, pomoże nagroda.

w. 6 Zyścieł im $k$ woli swemu obietnicy słowu - wypełnił słowa danej obietnicy (zob. Pwt 31, 20).

w. 7 egiptskie ogorki - symbol egipskich frykasów, za którymi tęsknili Izraelici wędrujący do Ziemi Obiecanej (zob. w. 31 i objaśnienie).

w. 8 aż po same dziorki - aż po dziurki w nosie, tj. w bród, pod dostatkiem. Zwrot przysłowiowy przez Potockiego stosowany na ogół w postaci: „Już ma wszystkiego po dziory” (NKPP, „nos” 25a).

w. 10 Jeruzalem - stolica państwa króla Dawida, święte miasto Żydów, będące symbolem narodu wybranego.

w. 11 Póttora tysiąca lat - okres pomiędzy początkiem istnienia ludu żydowskiego a niewolą babilońską (II tysiąclecie - 586 p.n.e.).

w. 12 Tyli jak wieprze w sadzu, jak $w$ maśle pampuchy - połączenie dwóch zwrotów przysłowiowych. Pierwszy przy innej okazji Potocki przytoczył w postaci: „Jesz, pijesz, tyjesz w sadło jako wieprz w karmniku” (NKPP, „tyć” 6), drugi, który w 1618 roku Salomon Rysiński zanotował w brzmieniu: „Ma się jako pączek w maśle”, poeta z Łużnej przywołał jako: „Niechaj w maśle rozkosznik opływa pampuchem” (NKPP, „pączek” a); w sadzu - w chlewie.

w. 13 ustawnie - ustawicznie, nieustannie.

w. 14 Bałwany czcza - mowa o złotym cielcu, stworzonym przez Aarona na prośbę Izraelitów pod nieobecność Mojżesza (zob. Wj 32, 1-6); ojczystemu Bogu Bogu swoich ojców.

w. 16 Abraham - pierwszy patriarcha, otrzymał od Boga obietnicę ziemi i licznego potomstwa (zob. Rdz 17, 19).

w. 18 ich na puszczy przeplewie - przetrzebi ich na pustyni.

w. 19 Żydów ogniste zabijały węże - por.: „Przetoż Pan przepuścił na lud węże ogniste, za których ranami i śmierciami barzo wielu przyszli do Mojżesza i rzekli: »Zgrzeszyliśmy, żechmy mówili przeciw Panu i tobie. Proś, aby oddalił od nas węże«" (Lb 21, 6-7a). Bóg powstrzymał karę ze względu na pamięć o przymierzu z Abrahamem: „Pamiętał wiecznie na testament swój, na słowo, które przykazał, na tysiąc narodów, które postanowił z Abrahamem, i na przysięgę swą z Izaakiem" (Ps 104[105], 8-9).

w. $20 z$ niemowiątek $-\mathrm{z}$ niemowląt. O duchowym rozwoju ludzkości tak pisał św. Paweł: „Gdym był dziecięciem, mówiłem jako dziecię, rozumiałem jako dziecię, myśliłem jako dziecię, lecz gdym się zstał mężem, wyniszczyłem, co było dziecinnego" (1 Kor 13, 11).

w. 21 Dosyć dwa tysiąca lat w rozum rość na człeka - nawiązanie do talmudycznej koncepcji periodyzacji dziejów (zob. Barr, 1985), którą Potocki przywołał w Przemowie do Transakcyi wojny chocimskiej: „Bo jeśli wedle zgadzających 
się profecyj sześć tysięcy lat ma stać structura huius universi [budowa tego świata], toć dwa tysiąca rość aże do czasów Abrahamowych i podania Zakonu Bożego, dwa tysiąca w perfekcyjej i sile aże do narodzenia Zbawiciela naszego, dwa tysiąca ad senectam [ku starości] i końcowi swemu” (Potocki, 1924, s. 359).

w. 23-24 do chleba, / Co trwalszy żywot daje - mowa o Mesjaszu; por.: „Ojcowie naszy jedli mannę na puszczy, jako jest napisano: »Chleb z nieba dał im jeść«. Rzekł im tedy Jezus: »Zaprawdę, zaprawdę mówię wam: nie Mojżesz wam dał chleb z nieba, ale Ociec mój daje wam chleb z nieba prawdziwy. Abowiem chleb Boży jest, który z nieba zstąpił i dawa żywot światu «" (J 6, 31-33).

w. 25 posilny $i$ on [...] tak syty - inwersja: ów pożywny i tak syty.

w. 26 śmierzy apetyty - zaspokaja głód.

w. 27-28 strucie, co na śmierć wiecznq nas kaleczy / W onem jabłku Ewinem - mowa o grzechu pierworodnym (zob. Rdz 3, 23).

w. 29 Trudno z błaznem na ryby, bo nie chce do wody - tj. trudno kogoś zmieniać na siłę; zwrot przysłowiowy, który przy innych okazjach Potocki przytaczał w postaci: „Z błaznem trudno na ryby”, czy: „Z błaznem do ślubu, jako i na ryby” (NKPP, „ryba” 62a).

w. 31 od ogórków, czo[sn]ku i cebule - por.: „Lud bowiem pospolity, który był wyszedł z nimi, chciwością był zapalony, siedząc i płacząc, przyłączywszy k sobie syny Izraelowe, i mówił: »Któż nam da mięsa do jedzenia? Wspominamy na ryby, któreśmy jadali w Egipcie darmo. Przychodzą na pamięć ogórki i malony, i łuczki, i cebule, i czosnki. Dusza nasza schnie, ninacz inszego nie patrzą oczy nasze jedno na man«" (Lb 11, 4-6).

w. 32 młosty mleka - skopki na mleko.

w. 35 skoro już miodu skosztowała mucha - tj. gdy w tym zasmakowali. Nawiązanie do zwrotu przysłowiowego, który przy innej okazji Potocki przytacza w postaci: „Jako mucha do miodu” (NKPP, „miód” 8c).

w. $38 \quad z w y c z a j o n e j ~ p a s z y$ - pożywienia, do którego już przywykli.

w. 36-40 Sens: Żydzi wyżej cenią wartości doczesne niż zbawienie, które daje wiara w Chrystusa. Wzmianka o Abrahamie jest nawiązaniem do konkluzji przypowieści o bogaczu i Łazarzu. Kiedy opływający w dostatki bogacz po śmierci znalazł się w Szeolu, dostrzegł znanego sobie za życia żebraka Łazarza na łonie Abrahama. „I rzekł: »Proszę cię tedy, ojcze, abyś go posłał do domu ojca mego, abowiem mam pięć braciej, aby im świadectwo wydał, iżby też oni nie przyszli na to miejsce mąk«. I rzekł mu Abraham: »Mają Mojżesza i proroki, niechże ich słuchają«. A on rzekł: »Nie, ojcze Abrahamie. Ale gdyby kto z umarłych szedł do nich, będą pokutę czynić«. I rzekł mu: »Jeśli Mojżesza i proroków nie słuchają, ani, by też kto z martwych powstał, nie uwierzą «" (Łk 16, 27-31).

w. 41-42 Potocki nawiązuje tu do oddania przywileju pierworództwa Ezawa za miskę soczewicy młodszemu bratu Jakubowi, odsyłając w marginalium do wersetu: 
„Rzekł Jakob: »Przysiężże mi«. I przysiągł mu Ezaw, i przedał pierworództwo” (Rdz 25, 33).

w. 43 marg. $\quad \dot{Z} y d z i$ poganom zbawienie - elipsa: Żydzi oddają zbawienie poganom (tj. innym ludom, które uwierzyły w Mesjasza). Potocki podąża za obowiązującą wykładnią opowieści o przejęciu pierworództwa Ezawa przez Jakuba, jaką Wujek zanotował w postaci tytuliku przy Rdz 27, 22: „Ta wszytka sprawa znaczyła, iż Bóg miał porzucić Żydy, a obrać na ich miejsce pogany”.

w. 44 Puszcza cug Ezawowi i do nieba przodek - tj. Żydzi oddają chrześcijanom możliwość zbawienia.

w. 46 Tłusta na świecie rola, olej, wino, zboże - parafraza wersetu, do którego Potocki odsyła w nocie marginalnej: „Dajżeć, Boże, z rosy niebieskiej i z tłustości ziemskiej obfitość zboża i wina” ( $\operatorname{Rdz} 27,28)$.

w. 47

Dał ci górę nad bratem i niskoć się kłaniał - por.: „I niech ci służą narodowie, i niech ci się kłaniają pokolenia. Bądź panem braciej twojej a niech się pochylają przed tobą synowie matki twojej" ( $\mathrm{Rdz} 27,29 \mathrm{a})$.

w. 50 potomstwo twemu Ezawowe służy - tj. potomkowie Ezawa służą twoim (Jakuba) potomkom.

w. 52 Dawszy pług Jakobowi, jemu miecz zostawi - parafraza obietnicy Izaaka danej Ezawowi, do której poeta odesłał na marginesie: „Z miecza żyć będziesz a będziesz służył bratu twemu, ale przydzie czas, kiedy zrzucisz i rozwiążesz jarzmo jego z szyje twojej" (Rdz 27, 40b).

w. 54 kowanej nie mógł mieć łopaty - nie miał łopaty kutej z metalu; por. werset, do którego poeta odsyła na marginesie: „Ale kowal nie najdował się we wszytkiej Ziemi Izraelskiej, bo opatrzyli byli Filistynowie, aby snadź Hebrejczycy nie uczynili miecza abo oszczepu" (1 Sm 13, 19).

w. 56 Saul - pierwszy król Izraela, pochodził z rodu Beniamina, panował ok. 1030-1010 p.n.e. (Zespół biblistów polskich, 2003, s. 1456); Filistynów ludu pochodzenia indoeuropejskiego, skonfliktowanego z Izraelitami. Filistyńczycy mieli przewagę dzięki broni żelaznej, na którą posiadali monopol handlowy (por. $1 \mathrm{Sm} \mathrm{13,19-22).}$

w. 59-60 mu to Izak przydał, a co dotąd panem, / Będzie też Ezawowi, Jakob zaś poddanem - mowa o błogosławieństwie Izaaka dla Ezawa (zob. objaśnienie do w. 52); Izak - Izaak, syn Abrahama, patriarcha, który z żoną Rebeką spłodził bliźnięta Ezawa i Jakuba.

w. 61 Dla Boga, azaż - Na Boga, czyż.

w. $62 A z a \dot{z}[\ldots]$ nie wszytkim poganom w korzyści? - tj. czyż nie są wykorzystywani przez wszystkie inne narody?

w. 63-64 Ale tam naprzód, którzy [...] / [...] Mesyjasza przejma - tj. a zwłaszcza przez chrześcijan.

w. 65 Nie tylko w pierworodztwie rzecz skazuje sama - tj. widać to nie tylko w oddaniu przez Żydów pierwszeństwa chrześcijanom.

w. 68 miecz i lemiesz obie - tj. i miecz, i pług; zob. objaśnienie do w. 52. 
w. 72-74 Sens: życie człowieka jest krótkotrwałe, ledwie zażyje rozkoszy, umiera, a zaraz po nim ci, którzy wytwarzają ziemskie rozkosze.

w. 76 bez niego i mleka, i miód brzuchy morzy - tj. spożywanie chleba jest podstawą żywienia.

w. 79 chceli go kto pożyć - tj. jeśli ktoś chce go spożywać, jeść.

w. 82

Idac na chlebne gody człek od tego mleka - tj. umierając, opuszczając doczesne rarytasy („mleko”) dla chleba w Królestwie Niebieskim; por.: „Błogosławiony, który będzie jadł chleb w Królestwie Bożym” (Łk 14, 15b).

w. 85 tak żałosne zświata przenosiny - tj. rozpacz po śmierci.

w. 86 ciężkie [...] zabija kliny - zadaje ciężki ból. musi się w niej schylić - tj. przed wejściem musi pocierpieć; por.: „Usiłujcie, abyście weszli przez ciasną fortkę, bo powiedam wam, że ich wiele będą chcieli wniść, a nie będą mogli” (Łk 13, 24).

w. 92 w nim wszytkie pokładał [...] kontentence - było źródłem każdej radości. wiecznem prawem w nim dziedziczę / Wczas i dobry byt ciała - tj. należą mi się wypoczynek i uciechy ciała; co pierwsza liczę - tj. co najważniejsze.

w. 95 ufortuni - obdarzy.

w. 97-98 acz jest inszym płocha, / Nie stawiła mi się ta fortuna macocha - choć innym nie zawsze sprzyja, ze mną to szczęście obeszło się łaskawie; nawiązanie do zwrotu przysłowiowego: „Fortunę wiedz być płochą, dziś matką, juto może być macochą” (NKPP, „szczęście” 73a).

w. 101 nie czując [...] w sercu swoim moli - tj. nie podlegając zgryzotom; utarty zwrot, przez Rysińskiego odnotowany w postaci: „Każdy ma swego mola, co go gryzie”, który w innym miejscu Potocki przywołał w brzmieniu: „Komu ból w głowie, bojaźń w sercu siedzi, zawsze mól gryzie” (NKPP, „mól” 1a).

w. 103 potrafiać - trafić, wcelować.

w. 104 jak na nić - tj. razem.

w. 105 odjąwszy mi dzieci - nawiązanie do zgonów dzieci poety: 22-letniego Stefana (zm. 20 XII 1673) i 22-letniej Zofii (zm. 11 V 1677), od 1669 roku żony starosty sądeckiego Jana Stanisława Lipskiego.

w. 106 co miał zdobić, honor, starość moję szpeci - tj. zamiast zaszczytów (radości), które miały przynieść mi dorosłe dzieci, dotyka mnie ich brak.

w. 107 się smęci - smuci się.

w. 108-109 łabęci / Mech - puch łabędzi, metonimia miękkich poduszek i lekkich kołder, tj. dobrych warunków do snu.

w. 107-110 Poeta polemizuje z przysłowiowymi radami konsolacyjnymi: „Wybije frasunek z głowy muzyk do lutnie gotowy” (NKPP, „frasunek” 13), „Na frasunek dobry trunek” (NKPP, „frasunek” 7), „Troska mniej boli, gdy ją przyjaciel podzieli” (NKPP, „przyjaciel” 115).

w. $112 \quad \dot{y} y c ́$ [...] ckliwo - przykrzy się życie.

w. $113 \quad$ A tó̇ mleczko, a toż miód-masz ci mleczko i miód (ironicznie). 
w. 115

w. 116

w. 117-118

łez rosołem - łzami żalu; nawiązanie do zwrotu przysłowiowego: „Być w rosole”, który Potocki stosował w formach: „Jako w rosole”, „Byłoby grzechem w tym was puszczać rosole”, „Już drugi dzień mija, jak w tym rosole mało jada, sypia, pija”, „W tym rosole zostawać” (NKPP, „rosół” 3); sierota - tj. osierocony przez dzieci.

się nim dopiero klnę - tj. przeklinam świat.

się [...] / [...] kwapię - śpieszę się; do [...] Jerycha - do najstarszego miasta świata, pierwszego, które zostało podbite przez Izraelitów w drodze do Ziemi Obiecanej (zob. Joz 6). W utworze Potockiego stanowi ono poetycką wykładnię przypowieści o uratowanym przez Samarytanina człowieku, który podróżował z Jeruzalem do Jerycha (zob. objaśnienie do tytułu i do towarzyszącego mu marginalium); Jerozolima jest metaforą świata doczesnego, a Jerycho nieba.

w. 119 marg. Por.: „I szedszy aż do strumienia Grona, urznęli gałąź winną z jagodą jej, którą nieśli na drągu dwa mężowie” (Lb 13, 24a).

w. 119-120 tych, co droga prosta / Chodza przed Toba - por.: „Bo proste drogi Pańskie, a sprawiedliwi będą nimi chodzili, ale przestępce poupadają na nich" $(\mathrm{Oz} 14,10 \mathrm{~b})$.

w. 122 Twoich świętych pasa - są drogą do świętości.

w. 123-124 namniej duszy / Nie da posiłku, ciało do godziny puszy - ciało zaspokajają tylko doraźnie, duszy nie przydając się na nic.

w. 126 ona sroga bania $w$ szczyptę prochu sklęśnie - por.: „Boś jest proch i w proch się obrócisz" (Rdz 3, 19b).

w. $128 \quad z ł o t a ~ s k i b a$ - najbardziej urodzajna ziemia, tj. łaska Boża, z nawiązką nagradzająca dobre uczynki.

w. 129 w tym wieku - tj. za życia.

w. 127-130 Poeta nawiązuje tu do przypowieści o siewcy (Mt 13, 1-9; Mk 4, 1-9; Łk 8, 4-8).

w. 131-132 smakiem i mleka, i miody / Doczesne przenoszące - tj. przewyższające doczesne rozkosze; por.: „Ale woda, którą mu ja dam, zstanie się w nim źrzódłem wody wyskakującej ku żywotowi wiecznemu" (J 4, 14).

w. 133-134 słodkiem chwały Twojej pieniem / [...] z ust świętych wypłynie strumieniem tj. w niebie święci i zbawieni będą opiewać Boga.

w. 135 pieszczoty - przyjemności.

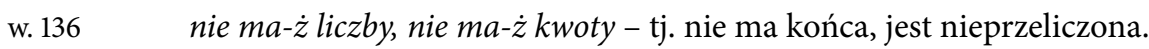

w. 140-141 Bo nigdy nie zachodzac, niebo Twe rumieni / Wieczne słońce - por.: „A miasto nie potrzebuje słońca ani księżyca, aby świeciły w nim, abo wiem jasność Boża oświeciła je, a świeca jego jest Baranek” (Ap 21, 23).

w. 142-143 w pomietle / Słońce świata być musi - tj. musi blednąć fizyczne Słońce; promień ciska jary - świeci mocny, jasny promień.

w. $145 \quad z[\ldots]$ pluty $-\mathrm{z}$ deszczu.

w. 146 mlekiem macierzystem struty - mowa o grzechu pierworodnym wyssanym z mlekiem matki; por. parafrazę wersetu: „Oto bowiem w nieprawościach 
jestem poczęty, a w grzechach poczęła mię matka moja” (Ps 50[51],7) pióra Jana Kochanowskiego: „Mnieć jeszcze złość w matce przeklęta zastała, / Mnieć grzech jeszcze w mleku matka podawała" (Psatterz Dawidów 51, w. 9-10).

w. 149-150 Tam bieże [...], gdzie mię wieczny z chlebem / Żywot czeka - zob. objaśnienie do w. 82 i do towarzyszącego mu marginalium.

w. 150 Kalebem - jednym ze zwiadowców wysłanych przez Mojżesza w celu zbadania krainy Kanaan (zob. Lb 13, 7); por.: „W tym Kaleb, hamując szemranie ludu, które się wszczynało przeciw Mojżeszowi, rzekł: »Pódźmy a posiądźmy ziemię, bo ją odzierżeć będziem mogli«" (Lb 13, 31).

w. 151 afekty - żądze, silne uczucia.

w. 153-154 żadna [...] posztą / [...] dosztą - do której nie da się dotrzeć żadnym koniem pocztowym, tj. rozum ludzki nie jest w stanie ogarnąć wysokości nieba empirejskiego.

w. 155 Cóż mówić o źrenicy śmiertelnego oka - por.: „Ale jako jest napisano: „Czego oko nie widziało i ucho nie słyszało, i w serce człowiecze nie wstąpiło, co nagotował Bóg tym, którzy go miłują «" (1 Kor 2, 9), w którym to wersecie przytoczone zostały słowa Iz 64, 3-4.

w. 157 możnali rzecz - tj. czy to rzecz możliwa, czy to może się stać.

w. 157-158 tam się zmieścić w ciele, / Gdzie sami tylko święci - według Nowego Testamentu zmartwychwstanie ciała nastąpi dopiero w momencie sądu ostatecznego, do tego czasu w niebie przebywa wyłącznie dusza ludzka (zob. 1 Kor 15, 20-38). w. 159-160 jedna bowiem noga / Na pół ziemie, druga stać na pół morza moga - parafraza wersetu, do którego Potocki odsyła w marginalium: „Postawił nogę swoję prawą na morzu, a lewą na ziemi” (Ap 10, 2b).

w. 161-162 sto ośmdziesiąt i pięć, kiedyś się użalił / Miasta swego, jeden z nich, tysięcy, powalit - nawiązanie do klęski Asyryjczyków pod Jeruzalem. Potocki odsyła do tej historii w marginalium: „Zstało się tedy, onej nocy przyszedł anioł Pański i pobił w oboziech asyryjskich sto ośmdziesiąt i pięć tysięcy. A wstawszy po ranu, ujźrzał wszytkie ciała umarłych, i odciągnąwszy odjachał" (2 Krl 19, 35).

w. 163 Szarańcza stosowany człowiek jest $z$ aniołem - aluzja do porównania z wersetu, do którego poeta odesłał w marginalium: „Tameśmy widzieli dziwy z synów Enak z rodu obrzymskiego, do których przyrównani, zdaliśmy się jako szarańcza" (Lb 13, 34).

w. 165 rozumu człowieczego biegiem - według kryteriów ludzkiego rozumu.

w. 166 Jozue, który stamtąd przyszedł szpiegiem - przywódca Izraelitów, który po śmierci Mojżesza wprowadził ich do ziemi Kanaan (zob. objaśnienie do w. 118). Był on drugim obok Kaleba zwiadowcą wysłanym do Kanaan, o czym informuje werset, do którego Potocki odsyła marginalium: „Ale Jozue, syn Nun, i Kaleb, syn Jefone, którzy też oględowali ziemię, rozdarli szaty swe" (Lb 14, 6). 
w. 170

w. 171

w. 175

w. 176

w. 177

w. 178

w. 180

w. 181

w. 181-182

w. 183

w. 184

w. $185-186$

w. 187

w. 188

w. 189

w. 192

w. 192-194 przed wieki urodzi - por.: „Na początku było Słowo” (J 1, 1a) i komentarz Wujka do tego wersetu: „To tedy Boskie Słowo było na początku wszytkiego stworzenia, było przed wieki, pierwej niżli co było uczyniono".

w zakładzie - jako zastaw.

w płóciennej kotarze - w namiocie.

Siedzi [...] jako ptak na szparze - tj. siedzi przerażony (jak ptak wystawiony w potrzasku jako przynęta dla drapieżnika); zwrot przysłowiowy, który Potocki przy innych okazjach przytacza w postaciach: „Siedział jako na wsparze”, „Trzymacie jak na szparze”, „Jakoby na szparze stanęli”, „Jakoby na szparze czekają”, „Go ma jakoby na szparze” (NKPP, „szpar, szpara”).

pociagnie nitki - zatrzaśnie pułapkę, tj. zabije.

wzleciawszy, niewczesne opuści przybytki - ulatując do nieba, opuści uciążliwe miejsce przebywania.

Między Jego [...] pisać się żotniérze - nawiązanie do wersetu: „Pracuj jako dobry żołnierz Chrystusa Jezusa. Żaden, służąc żołnierską Bogu, nie wikle się sprawami świeckimi, aby się temu podobał, któremu się udał" (2 Tm 2, 3-4). $W$ toż wstępując [...] strzemię - podążając tymże śladem, idąc za tym przykładem (NKPP, „strzemię” 4).

W toż wstępując $z$ Jozuem i $z$ Kalebem strzemię, / Święta onę [...] odziedziczy ziemię - naśladując Jozuego i Kaleba, wejdzie do Ziemi Obiecanej. Nawiązanie do wersetu wskazanego w marginalium: „Nie wnidziecie do ziemie, o którą podniosłem rękę moję, żebym wam mieszkać dał, oprócz Kaleba, syna Jefone, a Jozue, syna Nun” (Lb 14, 30); zob. objaśnienie do w. 150 i marginalium, oraz do w. 166 i marginalium.

kinąwszy [...] postrachy - porzuciwszy lęki.

pobieram się - wybieram się, idę.

$z$ dzisiejszem podróżnem, / Lecz nie tak, jako $w$ drodze, trzeba być ostrożnem tj. na drodze do nieba czyhają inne niebezpieczeństwa niż na ziemskich drogach w czasach Potockiego.

drzymiąc, nikczemna myśl mnie ubezpiecza - nieostrożnie, w swej naiwności czując się bezpiecznym.

Nie śni mi się o zdradzie - nie spodziewam się podstępu; Ni tarcze, ni miecza tj. nie mam pod ręką ani tarczy, ani miecza.

miasto boku - zamiast przy boku, u pasa; por.: „We wszytkim biorąc tarczą wiary, którą byście mogli wszytki strzały ogniste złośliwego zgasić, i przyłbicę zbawienia weźmicie, i miecz ducha (które jest Słowo Boże)" (Ef 6, 16-17). bezpiecznie - bezbronny lub beztroski.

Parafraza wersetów, z których pierwszy Potocki wskazał marginalną notą: „Wchodźcie przez ciasną bramę, abowiem szeroka brama i przestrona jest droga, która wiedzie na zatracenie, a wiele ich jest, którzy przez nię wchodzą. Jakoż ciasna brama i wąska jest droga, która wiedzie do żywota, a mało ich jest, którzy ją najdują" (Mt 7, 13-14). 
w. 196

w. 199

w. 199-201

w. 202

w. 203

w. 205

w. 207

w. $209-210$

w. 211 marg.

w. 212

w. 213

w. 214

w. 215 marg.

w. 216

w. 219 spadna - napadną.

Wyprosić nie pomyślać - nie do pomyślenia jest wybłaganie litości.

wzrok ich [...] / Owe srogie rozjadłe wyraża jaszczury, / Seppy albo [...] harpije - ich wzrok podobny jest do oczu rozwścieczonych jaszczurów, sępów lub harpii; harpije - harpie; w mitologii greckiej agresywne duchy przedstawiane jako uskrzydlone kobiety albo ptaki z ludzką głową, z ostrymi szponami, córki Taumasa i Okeanidy Elektry (Grimal, 2008, s. 119).

zobia - pokarmem.

w onym [...] huku - tj. w tej awanturze. W tym miejscu Potocki przechodzi do wzorowanej na rycinie Hieronima Wierixa (Spirituale Christiani militis certamen z 1591 lub Spiritale [!] Christiani militis certamen sprzed 1610, zob. Grześkowiak, 2018, s. 226-241 oraz ilustracja do niniejszej edycji) prezentacji ukazującej pięciu metafizycznych przeciwników żołnierza Chrystusowego: Szatana, Grzech, Śmierć, Świat, Ciało.

betty ogniste - zob. objaśnienie do w. 189 i do towarzyszącego mu marginalium. Grzech, ten węża rajskiego kibici - odwołanie do ryciny Wierixa, na której Grzech przedstawiono jako hybrydę człowieka i węża, nawiązując do kuszenia Adama i Ewy w raju przez szatana pod postacią węża. Potocki odsyła do tej historii w marginalium: „Ale i wąż był chytrszy nad inne wszytkie źwierzęta ziemne, które był Pan Bóg stworzył. Który rzekł do niewiasty: „Czemu wam Bóg przykazał, żebyście nie jedli z każdego drzewa rajskiego?«” ( $\operatorname{Rdz} 3,1)$. sprosna paszczeka, skąd miasto języka / Tysiacem [...] żądeł na mię kszyka odrażającą paszczą, z której zamiast językiem syczy na mnie tysiącem żądeł. Por.: „A oto koń blady, a który siedział na nim, imię jemu Śmierć, a piekło szło za nim, i dana mu jest moc nad czterzmi częściami ziemi zabijać mieczem, głodem i śmiercią, i przez bestyje ziemskie" (Ap 6, 8).

wyniesiona kosę - uniesioną kosę. Zgadza się to $\mathrm{z}$ wizerunkiem Śmierci na grafice Wierixa.

krew moich [...] dzieci - zob. objaśnienie do w. 105.

Siarczystemi - obfitymi.

Por.: „Abowiem wszytko, co jest na świecie, jest pożądliwość ciała i pożądliwość oczu, i pycha żywota, która nie jest z Ojca, ale jest z świata" (1 J 2, 16). kusz - czara, puchar. Personifikacja Świata, kusząca bogactwem i ziemskimi rozkoszami, ukazana została na wzór nierządnicy babilońskiej z wizji św. Jana, do której Potocki odsyła w marginalium: „A niewiasta przyobleczona była w purpurę i w karmazyn, i uzłocona złotem, i drogim kamieniem, i perłami, mając kubek złoty w ręce swej, pełny brzydliwości i plugastwa wszeteczeństwa swojego" (Ap 17, 4).

jako łẹ $[t]$ goły - tj. nagi jak łodyga; zwrot przysłowiowy, który Potocki przytacza także w postaci: „Odymasz się jak jeż, będąc jak łęt gołym”, „Próżno się Lisem piszesz, kiedyś jak łęt goły” (NKPP „goły” 12). Por.: „A jeśli ręka twoja abo noga twoja gorszy cię, odetni ją i zarzuć od siebie. Lepiej ci tobie 
ułomnym abo chromym wniść do żywota, niżli mając dwie ręce abo dwie nodze, być wrzuconym w ogień wieczny" (Mt 18, 8).

w. 222 Od [...] chlebojedźce - tj. ze strony ciała.

w. 223 próżne były treny - na nic zdały się żale, płacze.

w. 225-226 co gotowizny / Było, wzięli - tj. ukradli wszystkie pieniądze, jakie miałem. Odsyłacz do tego wersetu towarzyszy tytułowi poematu; zob. objaśnienie do tytułu i marginalium przy nim.

w. 227 Suchych razów - tj. ciosów, które nie pozostawiają krwawych śladów.

w. 229-231 ruszony niewczesnej miłosierdziem chuci, / [...] gałęziem przyrzuci, / Miasto barwierza, miasto [...] ran zawoju - pod wpływem nagłego przypływu spóźnionego miłosierdzia przykryje (dającą cień) gałęzią, zamiast wezwać balwierza (wykonującego proste zabiegi chirurgiczne), opatrzyć rany.

w. 233-234 strachu, który / Wszytko złe przenosi, ból i strach śmierci wtóréj - w strachu, który przewyższa całe zło, ból i strach przed piekłem.

w. 235 Źlem rzekł [...] $z$ dusznego rozbicia - z powodu zagrożenia zbawienia źle się wyraziłem. Correctio, figura retoryczna stosowana w celu wzmocnienia określenia.

w. 235-236 nie śmierci wtórej [...] / I ból, i strach wtórego przenosi ożycia - tj. nie przewyższa strachu przed śmiercią, ale strach przed zmartwychwstaniem i sądem ostatecznym (w domyśle: wiecznym potępieniem).

w. 237 członka-części.

w. 238 do ścierwu - do padliny.

w. 239 się [...] warta - błąka się.

w. 245 Bóg mi wysoko, przyjaciel daleko - tj. zostałem zupełnie sam; zwrot przysłowiowy, który Rysiński odnotował w postaci: „Bóg wysoko, a przyjaciel daleko” (NKPP, „Bóg” 103).

w. 246 Jużże Jego zapadło miłosierdzia wieko - wszystko stracone, nic już nie można zrobić; nawiązanie do zwrotu przysłowiowego: „Jeszcze wieko nie zapadło” (NKPP, „wieko”).

w. 247-249 w nadziei żywota / Stychiwałem czyniących na szubieńcy wota / I nie były daremne! - zapewne nawiązanie do nawrócenia przed śmiercią jednego $\mathrm{z}$ dwóch łotrów ukrzyżowanych razem z Jezusem (zob. Łk 23, 39-43).

w. 251

Nadzieja wszyscy stojem - nawiązanie do zwrotu przysłowiowego: „Nadzieją człowiek żyje” (NKPP, „nadzieja” 30).

w. 251-252 pierwsza zaraz bierze / [...] nadzieja przy wierze - tj. nadzieja ma miejsce zaraz po wierze.

w. 257 wiatrem nazwać może - tj. jest niestała, nieobliczalna (jak wiatr)

w. $258-259$ miłosierdzie [...] / przeciw [...] stworzeniu - miłosierdzie wobec stworzenia. gdzie szczęście przytaczać - wobec którego wspominać fortunę. w. 262 na tym Bieszczadzie - znane poecie $\mathrm{z}$ autopsji pełne zbójców Bieszczady stanowią peryfrazę zagrażających duszy niebezpieczeństw światowych; por. np.: „»Albo daj, aboć wydrą" - tu, między Bieszczady, / pospolicie jej 
skutek panuje szkarady, / stąd rozboje okrutne, stąd są zasiadania / na drogach od zaranku aże do świtania”; „A co większa, gorzej tam niżli na Bieszczedzie, / gdzie tylko złoto biorą, puściwszy, kto jedzie, / tam zaś srogich zasiadło rozbójników kilko, / złota nie pragną, ale śmierci ludzkiej tylko" (Trembecki, 1911, s. 56, 63 [W. Potocki, Rozkosz światowa, Rozkosz duchowna, w. 159-162, 397-400]).

w. 264

W. 265

w. 266

W. 268

w. 271

W. 272

w. 273

w. 274

W. 280

w. 281

w. 283-284

w. 289

w. 292

w. 294

w. 298

w. 300

w. 302 marg

W. 303

w. 302-304

Pośle mu cyrulika - przyśle mu balwierza (zob. objaśnienie do w. 231), tj. Bóg mu pomoże.

dusza - duszo (dawny wołacz).

człowiek tonący i brzytwy się chwyta - zwrot przysłowiowy (NKPP, „tonący” 4). Przy innych okazjach Potocki przytaczał go w postaci: „Wiesz dobrze, mój kochany [...] towarzyszu, / że się chwyta tonący brzytwy, chwyta wiszu”, „Chwyta się i wiszu, chwyta ostrej, gdy komu o reszt chodzi, brzytwy” (NKPP, „tonący” 4b), „Acz się i brzytwy zwykle chwytamy, gdy toniem”, „Tonący, jako mówią, chwyta się i brzytwy”, „Chwytać się tonącemu brzytwy” (NKPP, „tonący” 4c).

wskoki - szybko, od razu.

będziesz ostrożniejszy na zbawiennej drodze - zob. objaśnienie do w. 194.

przybierzesz narowom Ciała swego wodze - tj. będziesz umiał trzymać cielesne żądze na wodzy; aluzja do zwrotu przysłowiowego: „Trzymać na wodzy (w cuglach)” (NKPP, „wodze” 4).

do nieba ciasna poprowadzi ścieżka - zob. objaśnienie do w. 192-194.

nie weźmiesz od Świata wina ani mieszka - zob. w. 216 i objaśnienie.

nie uderzysz płazq - nie będziesz pobłażać; zwrot przysłowiowy: „Puścić płazem” (NKPP, „płaz”).

przestrzegać - uważać, strzec się.

kędy rad uprzędzie / Za lada okazyja - do którego się dostanie przy byle okazji. zaboje w swym domu - zabójstwa w swojej rodzinie; zob. w. 105 i 213-214 oraz objaśnienia.

Co dat, wolno mu znowu wziąć wedle swej woli - nawiązanie do wyznania Hioba: „Pan dał, Pan odjął” (Hi 1,21a), które stało się przysłowiowe: „Bóg dał, Bóg wziął” (NKPP, „Bóg” 60). W innym swym tekście Potocki przywołał zwrot w postaci: „Bóg daje, Bóg odbiera swoje ludziom dary” (NKPP, „Bóg” 60a). winne - które jest winien, do którego jest zobowiązany.

W karaniu zaś leniwy albo miłosierny - por.: „Litościwy i miłościwy Pan, długo czekający a wielce miłosierny” (Ps 102[103], 8).

Wieleś razy dekret swój, choć już pod pieczęcia, / Wydany na człowieka $z$ wielka niszczeł chęciq - zob. objaśnienie do w. 16-19.

Por.: „I utrapiony jest Jonasz utrapieniem wielkim, i rozgniewał się” (Jon 4, 1). chybi - nie spełni się.

W tym miejscu poeta odwołuje się do historii Jonasza, który z polecenia Boga miał udać się do stolicy Asyrii, Niniwy, i namówić jej mieszkańców, żeby 
zaniechali niegodziwości. Prorok nie chciał spełnić prośby Boga i popłynął w odmiennym kierunku. Wówczas rozpętała się burza i Jonasz zdał sobie sprawę, że to oznaka gniewu Bożego, poprosił więc załogę, by wyrzuciła go za burtę. Mężczyzna nie utonął, lecz został połknięty przez ogromną rybę, w której brzuchu spędził trzy dni (zob. Jon 1-2).

w. 305 Już był na śmierć osądzon Ezechijasz wrzodem - z powodu wrzodu dni Ezechiasza były już policzone; Ezechijasz - Ezechiasz, król Judy, panował w latach ok. 728-699 p.n.e. (Zespół biblistów polskich, 2003, s. 1458). Por.: „»Proszę, Panie, wspomni, proszę, jakom chodził przed Tobą w prawdzie i w sercu doskonałym a czyniłem, co się przed Tobą podobało«. Płakał tedy Ezechijasz płaczem wielkim" (2 Krl 20, 3a).

w. 308 marg. Por.: „Wyzwał tedy Izajasz prorok Pana i wrócił cień przez linie, po których już był stąpił na zegarze Achaz ma wstecz dziesięć stopniów” (2 Krl 20, 11).

w. 309 marg. Por.: „I rzekł Izajasz: »Przynieście wiązankę fig«. Którą gdy przynieśli i położyli na wrzód jego, uzdrowion był" (2 Krl 20, 7).

w. 305-310 Poeta nawiązuje do historii Ezechiasza, do której opisu odsyła w marginaliach. Mężczyzna zachorował śmiertelnie i modlił się do Boga. Jego prośby zostały wysłuchane, co w imieniu Boga przekazał mu Izajasz. Uzdrowiono Ezechiasza pęczkiem fig (tak w przekładzie Wujka, we współczesnych tłumaczeniach mowa o placku figowym). Ezechiasz chciał dostać cudowny znak, świadczący o uzdrowieniu, poprosił więc, żeby cień na zegarze słonecznym cofnął się o dziesięć stopni. Bóg spełnił prośbę i nakazał Ezechiaszowi pójście do świątyni trzy dni po uzdrowieniu ( $2 \mathrm{Krl} 20,1-11)$.

w. 311-313 Fragment inspirowany opisem choroby Hioba: „Wyszedszy tedy szatan od oblicza Pana, zaraził Joba wrzodem barzo złym, od stopy nogi aż do wierzchu głowy jego. Który ropę skorupą oskrobywał, siedząc na gnoju” (Hi 2, 7-8).

w. 316 grzechów kancerem [...] zastrupi - zabije rakiem (wrzodem) grzechu; kancer w czasach Potockiego słowo oznaczało zarówno złośliwego guza (raka), jak i wrzód.

w. 322 we mnie nic dobrego od pierwszego wzrostu - tj. od najmłodszych lat nie spełniałem dobrych uczynków.

w. 324 słońce nie zasiędzie - słońce nie zatrzyma się. Nawiązanie do historii Ezechiasza (zob. objaśnienie do w. 305-310).

w. 325 Pozwólże mi [...] czasu - daj mi czas.

w. 328 na mą morówkę - na moją chorobę (dżumę).

w. 333 któryś woda świat zalewał, Boże - nawiązanie do potopu zesłanego przez Boga (zob. Rdz 6-7).

w. 335-336 nie tu / Czynieł egzekucyja [...] dekretu - nie teraz wykonywał wyrok.

w. $340 \quad z$ niewczasu - z niewygody, z przykrości.

w. 345-346 Nie tak ludziom nauki w postuch ida rady, / Jako $w$ mistrzach przystojnych uczynków przykłady - nawiązanie do łac. paremii „Verba docent, exempla trahunt” i jej polskich inkarnacji, które Potocki w innym tekście przywoływał 
w postaci: „Rychlej sprawisz przykładem aniżeli słowy” (NKPP, „przykład” 9a), „Długa [...] w nauce droga, lecz w przykładzie i krótka, i skuteczna” (NKPP, „przykład” 9b).

w. 349 w pół nie stało pary - tj. nie zdołałem dokończyć słowa.

Bóg mówi: „Miłosierdzia chcę, a nie ofiary” - cytat z Ewangelii św. Mateusza oznaczony przez Potockiego na marginesie: „»Miłosierdzia chcę, a nie ofiary«, bom nie przyszedł wzywać sprawiedliwych, ale grzesznych” (Mt 9, 13), w Nowym Testamencie będący przytoczeniem wersetu: „Bom miłosierdzia żądał, a nie ofiary” (Oz 6, 6a), odróżniającego pobożność prawdziwą do powierzchownej.

w. 351 lewita - przedstawiciel jednej z grup pomocników kapłańskich, zajmujących się pilnowaniem i sprzątaniem świątyni oraz przygotowywaniem liturgii.

w. 353 barbierza - zob. objaśnienie do w. 231.

w. 360 Samarytan - Samarytanin, członek semickiej grupy etniczno-religijnej, wykluczonej ze wspólnoty judaizmu, ponieważ nie zaprzestała kultu bożków (por. $2 \mathrm{Krl}$ 17, 25-41 i objaśnienie).

w. 366 wysługi - przysługi, pomocy.

w. 370 po lekku - powoli.

w. 372

$O$ [...] wczasie - tj. o wypoczynku, o komforcie.

w. 375 miej o tym człeku pilną piecza - zaopiekuj się troskliwie tym człowiekiem.

w. 378 do halerza - tj. co do grosza. potomka przeklętego Chama - Cham, jeden z trzech synów Noego, został przeklęty wraz z potomstwem za naśmiewanie się z pijanego ojca, który leżał nagi ( $\operatorname{Rdz} 9,18-27)$.

w łupież wężowy - tj. w skórę węża. Nawiązanie do kuszenia w raju (zob. Rdz 3).

w. 386 starozakonna litera zabija - mowa o surowym prawie starotestamentowym. Potocki notą marginalną wskazuje werset, do którego się odwołuje: „Który też uczynił nas godnymi sługami Nowego Testamentu, nie literą, ale Duchem, bo litera zabija, a Duch ożywia" (2 Kor 3, 6).

w. 389 Elijasz, co umartych wskrzesza - nawiązanie do historii proroka Eliasza (IX w. p.n.e.), który w Sarepcie wskrzesił syna wdowy. Potocki w marginalium odsyła do wersetu mówiącego o tym wydarzeniu: „I wysłuchał Pan głos Elijaszów, i wróciła się dusza dziecięcia weń, i ożyło” (1 Krl 17, 22).

w. 390 Mojżesza - Mojżesz (ok. XIII w. p.n.e.), prorok i przywódca Izraelitów podczas ich wyjścia z Egiptu.

w. 392 nie ma- $\dot{z}$ wina i oliwy - tj. brak miłosierdzia. Reprezentanci starotestamentowego Prawa (Mojżesz) i proroków (Eliasz) nic nie wskórają bez nowotestamentowej nauki o miłosierdziu.

w. 393 ranniéj - wcześniej.

w. 395 marg. Por.: „I było tam sześć stągiew kamiennych, według oczyścienia żydowskiego postanowionych, biorących w się każda dwie abo trzy wiadra” (J 2, 6). 
w. 394-396 Mowa o cudzie w Kanie Galilejskiej, gdzie Jezus na weselu przemienił wodę w wino (zob. J 2, 1-11).

w. 397-400 Poeta nawiązuje tu do śmierci Jezusa na krzyżu; w wersecie, do którego autor odsyła w marginalium, czytamy o niej: „Ale jeden z żołnierzów otworzył włócznią bok jego, a natychmiast wyszła krew i woda” (J 19, 34).

w. 401-404 Sens: dzięki chrztowi świętemu i ofierze Jezusa na krzyżu człowiek może zostać zbawiony. Por. wersety przywołane na marginesie: „Kto uwierzy i ochrzci się, zbawion będzie, a kto nie uwierzy, będzie potępion” (Mk 16, 16), oraz: „Zaprawdę, zaprawdę wam powiadam: jeślibyście nie jedli ciała Syna Człowieczego i nie pili krwie Jego, nie będziecie mieć żywota w sobie” (J 6, 53b). $W$ bydlęcej j[u]sze Mojżesz [...] narza - por. przekazane przez Mojżesza reguły składania ofiar całopalnych z bydła: „I ofiaruje cielca przed Panem, i będą ofiarować synowie Aaronowi, kapłani, krew jego, wylewając wkoło ołtarza, który jest przede drzwiami przybytku" (Kpł 1, 5).

w. 410 śmierzy - tj. łagodzi.

w. 413 Dałeś $z$ siebie i chusty, dałeś szatę zdzierać - nawiązanie do drogi krzyżowej i odarcia Chrystusa z szat (zob. Mt 27, 28; J 19, 23).

w. 415 flejtuchy - opatrunki.

w. 417 Zsiadteś z konia, o Jezu, na tę niską ziemię - nawiązanie do apokaliptycznego wizerunku Chrystusa: „I widziałem niebo otworzone, a oto koń biały, a który siedział na nim, zwano go Wiernym i Prawdziwym, a sądzi z sprawiedliwością i walczy” (Ap 19, 11).

w. 419 trzydzieści i pótczwarta roków - tj. ponad 33 lata.

w. 424 Podjawszy [...] piecza - tj. sprawując opiekę.

w. 427 Znalazteś mi gospodę w tego świata mieście - na potrzeby poetyckiej egzegezy przypowieści o miłosiernym Samarytaninie Potocki przywołuje zwrot przysłowiowy: „Bo ten świat nie jest nasz dom, ale jest gospoda, / która tu nam z urzędu jest dana od Boga” (NKPP, „świat” 105).

w. 428 swe obeście - tj. swój majątek, swoje mienie.

w. 431 za delikackiem [...] stołem - za stołem pełnym wyszukanych potraw.

w. 435-436 na głowie do włosa / Poruczeł - powierzył całego (dosłownie aż do jednego włosa na głowie), nawiązanie do słów: „Aleć i włosy głowy waszej wszytkie są zliczone" (Łk 12, 7); por. też Mk 10, 30.

w. $438 \quad w$ dziesięcioro - tj. dziesięciokrotnie. Nawiązanie do obietnicy: „Zaprawdę powiadam wam, iż wy, którzyście szli za mną, w odrodzeniu, gdy usiędzie Syn Człowieczy na stolicy majestatu swego, będziecie i wy siedzieć na dwanaście stolicach, sądząc dwojenaście pokolenia Izraelskie. I wszelki, który by opuścił dom abo bracią, abo siostry, abo ojca, abo matkę, abo żonę, abo syny, abo role dla imienia mego, tyle stokroć weźmie i żywot wieczny odzierży" (Mt 19, 28b-29).

w. $440 \quad$ zadatek iścizny - zaliczka należności. 
w. 442 szafuje Duch Święty - zarządza Duch Święty. Po wstąpieniu Jezusa do nieba Duch Święty w sposób niewidzialny działa w Kościele poprzez Słowo Boże, modlitwę, dary i sakramenty.

w. $447 \quad w$ kolei - w koleinie.

w. $450 \quad$ nad rozbitem - nad ofiarą napaści.

w. $460 \quad \dot{z}$ ebyś go równał $z$ cherubinem - tj. żebyś go przyrównywał do anioła, który może przybywać w niebie bezpośrednio przed obliczem Boga.

w. 462 mało na trzech onych mając - tj. nie zważając na Osoby Trójcy Świętej, o których mowa w w. 459-460.

w. $463 \quad z[\ldots]$ przynuki - z przymuszenia.

w. 469 Cię znam swym lekarzem - nawiązanie do słów Jezusa: „Zdrowi nie potrzebują lekarza, ale którzy się źle mają. Abowiem nie przyszedłem wzywać sprawiedliwych, ale grzesznych" (Mk 2, 17b); moja rana - mowa o grzechu pierworodnym.

w. 471-478 Sens: jeśli człowiek świadomie będzie grzeszył (prowokował diabła do ataku na duszę), może zostać wykluczony ze wspólnoty Kościoła i trafi do piekła, gdzie nigdy nie zagoi ran duszy.

w. 478-479 Nuż niespodziewany / Powrócisz? - por. np.: „Przetoż i wy bądźcie gotowi, bo której godziny nie wzwiecie, Syn Człowieczy przydzie” (Mt 24, 44).

w. $481 \quad$ Aluzja do przypowieści o talentach (Mt 25, 14-30).

w. 482 karb zaraz za pasem - tj. kij, na którym oznacza się stan liczebny (tu: popełnionych grzechów), masz pod ręką.

w. 484 do smoły - tj. do piekła.

w. $487 \quad z$ tych groszów pary - zob. w. 373 i 436-437.

w. 490-491 gdzie się / Pobierać z tego świata - gdzie (do jakich zaświatów) wybrać się po śmierci.

w. $494 \quad$ tymże strzyże - tym tnie, zadaje rany.

w. 495 Psuja - marnują; nie chca się jąć hafty - nie trzymają szwy.

w. 497 nad wszytkie Eskulapijusze - tj. od wszystkich lekarzy. W mitologii rzymskiej Eskulap był bogiem sztuki lekarskiej (gr. Asklepios). Posiadł specyfik z krwi prawych żył Gorgony i dzięki niemu wskrzeszał ludzi (zob. Grimal, 2008, s. 44-45).

w. 499 Strzyż złe mięso - przycinaj dzikie mięso (mowa o nadmiernym rozroście tkanek przy źle gojących się ranach). Mięso rozumiane jako cielesność stanowi metonimię grzeszności człowieka.

w. 500 szkapa - lichy koń. Mowa o nieposłusznym ciele; trzymaj palec $w$ sadnie trzymaj palec w ranie, tj. kiełznaj; zwrot przysłowiowy (NKPP, „sedno” 2).

w. 501 swych groszów - zob. w. 373, 436-437, 487.

w. 502 kupić armature - tj. zaopatrzyć się w zbroję.

w. 503 jego [...] orda - tj. szatańscy sprzymierzeńcy. 
Twego Słowa korda - miecza Słowa Bożego; por. „miecz ducha (które jest Słowo Boże)" (Ef 6, 17b). Kord był jednosieczną bronią o lekko zakrzywionej głowni, która wykształciła się na zachodzie Europy w XIV i XV wieku.

w. 505 marg. Na kanwie ustępu z Listu św. Pawła do Efezjan Potocki wyszczególnia elementy uzbrojenia Chrystusowego żołnierza; por.: „Stójcież tedy, przepasawszy biodra wasze prawdą, a oblókszy pancerz sprawiedliwości i obuwszy nogi w gotowość Ewangelijej pokoju” (Ef 6, 14-15) oraz objaśnienie do w. 189 i do towarzyszącego mu marginalium.

w. 505-506 Niechaj Twe obietnice, Twe straszliwe grozy / Między Twych kawalerów wpisza mnie obozy - tj. dzięki Twym obietnicom życia wiecznego i groźbom piekielnym dołączę do wojska Twoich rycerzy.

w. 508 się składat - osłaniał się.

w. 509-510 Abraham ukazuje stary, / Że nigdy być nie może lepsza jako $z$ wiary - nawiązanie do historii Abrahama, któremu Bóg nakazał złożyć ofiarę z pierworodnego syna, Izaaka, na dowód bezgranicznej wiary (zob. Rdz 22).

w. 508-510 Tarczę na jego strzały [...] / Trzeba [...] / [...] z wiary - por.: „We wszytkim biorąc tarczą wiary, którą byście mogli wszytki strzały ogniste złośliwego zgasić" (Ef 6, 16).

w. 511-512 Choćbym gór nie przenosiet, Panie, obdarzże mię / Wiarą, żebym nia w niebo siebie przeniósł z ziemie - por.: „I chociabych miał proroctwo, i wiedziałbych wszytkie tajemnice i wszelką naukę, i miałbym wszytkę wiarę, tak iżbych góry przenosił, a miłości bych nie miał, nicem nie jest” (1 Kor 13, 2).

w. 513 w okazyjej - w potyczce, w bitwie.

w. 513-514 szyszak codzienny, / [...] ze spiże nadzieje zbawiennéj - por.: „przyłbicę zbawienia weźmicie” (Ef 6, 17a). W tekście Potockiego mowa o zakończonym spiczasto hełmie, wchodzącym w skład dawnej zbroi.

w. 517 nic bystrszego - nic szybszego.

w. 519 Blachu trzeba, który by pierś śmiertelna szczycieł - potrzeba zbroi chroniącej ciało.

w. 522 nie przeskrobie - nie ugodzi.

w. 524 Daj tylko swej miłości, mym piersiom załogi - miłość Jezusa powinna być główną częścią zbroi (osłaniać pierś).

w. $525 \quad$ oczu [...] łupić - oczy wydłubać. Nawiązanie do słów Jezusa: „A jeśliby ręka twa gorszyła cię, odetni ją. Lepiej jest tobie wniść do żywota ułomnym, niż mając obie ręce, iść do piekła w ogień nieugaszony, gdzie robak ich nie umiera a ogień nie gaśnie. A jeśli cię noga twoja gorszy, utni ją. Lepiej jest tobie wniść chromym do żywota wiecznego, niż mając obie nodze, być wrzuconym do piekła ognia nieugaszonego, gdzie robak ich nie umiera, a ogień nie gaśnie” (Mk 9, 42-45). Por. objaśnienie do w. 219.

w. 526-527 pancerz [...] / Świętej sprawiedliwości - por.: „oblókszy pancerz sprawiedliwości” (Ef 6, 14b). 
w. 527-528 naprzód Tobie, / Co należy, też ludziom oddawat - nawiązanie do słów Jezusa: „Oddajcież tedy, co jest cesarskiego, cesarzowi, a co jest Bożego, Bogu” (Mk 12, 17b).

w. 529 prawdy [...] przepasany sznurem - por.: „Stójcież tedy, przepasawszy biodra wasze prawdą" (Ef 6, 14a).

w. $532 \quad$ w ustawicznej - tj. w nieustannej.

w. 533-534 któryś zginionemu światu na ratunek / Z nieba zstąieł - nawiązanie do zejścia Jezusa na ziemię: „Bom zstąpił z nieba, nie iżbych czynił wolą moję, ale wolą onego, który mię posłał" (J 6, 38).

w. $537 \quad W[\ldots]$ komput - tj. w skład, w liczbę.

w. $538 \quad$ w kuźni niebieskiej - tj. w niebie empirejskim.

w. 539 nienaruszonem [...] kirysem - pancerzem nie do przebicia.

w. 540 przyjdziesz na świat ostatniem popisem - nawiązanie do ponownego przyjścia Jezusa na ziemię i do sądu ostatecznego (zob. Mt 24, 27-31; 25, 31-46; Mk 13, 24-27; Łk 21, 25-28; J 6, 38-40).

w. $542 \quad z$ tego zbiera - nad tą zgrają, zbiorowiskiem (mowa o opisanych wyżej pięciu metafizycznych przeciwnikach).

\section{Bibliografia podmiotowa}

Potocki, W. (1924). Transakcyja wojny chocimskiej. Wyd., oprac. A. Brückner. Kraków: Krakowska Spółka Wydawnicza.

Trembecki, J.T. (1911). Wirydarz poetycki. Wyd. A. Brückner. T. 2. Lwów: Towarzystwo dla Popierania Nauki Polskiej.

\section{Bibliografia przedmiotowa}

Barr, J. (1985). Why the world was created in 4004 B.C.: Archbishop Ussher and Biblical chronology. Bulletin of the John Rylands Library, 67 (2), 575-608.

Brückner, A. (1898). Spuścizna rękopiśmienna po Wacławie Potockim. Cz. 1. Kraków: Akademia Umiejętności.

Grimal, P. (2008). Słownik mitologii greckiej i rzymskiej. Przeł. M. Bronarska i in. Wrocław: Zakład Narodowy im. Ossolińskich.

Grześkowiak, R. (2018). Dialogi dzieł dawnych. Studia o intertekstualności literatury staropolskiej. Gdańsk: Wydawnictwo Uniwersytetu Gdańskiego.

Kukulski, L. (1962). Prolegomena filologiczne do twórczości Wacława Potockiego. Wrocław: Zakład Narodowy im. Ossolińskich.

Malicki, J. (1980). Wacława Potockiego „Rozbój duchowny”. W: T. Ulewicz (red.), Miscellanea staropolskie (s. 223-256). Wrocław: Zakład Narodowy im. Ossolińskich. 
Zespół biblistów polskich (2003). Tablica chronologiczna. W: Pismo Święte Starego i Nowego Testamentu w przekładzie z języków oryginalnych (s. 1455-1464). Oprac. zespół biblistów polskich z inicjatywy benedyktynów tynieckich. Wyd. 5. Poznań: Pallottinum.

\section{"Spiritual Warfare" by Wacław Potocki. Commented critical edition}

\section{Summary}

This paper presents the second critical edition of the poem "Rozbój duchowny" ("Spiritual warfare") written by Polish poet from $17^{\text {th }}$ century Wacław Potocki. The first edition, published in 1980, prepared by Jan Malicki, has some editorial mistakes, hence the poem was edited again. The commentaries explain biblical and mythological references, the meaning of Old-Polish words as well as the proverbs. The author also points out to the relationship between the text of the poem and work "Spirituale Christiani militis certamen" by Antwerp engraver Hieronymus Wierix and describes the theme of the knight of Christ as a leitmotiv in Potocki's poems.

Słowa kluczowe: Wacław Potocki, rycerz Chrystusowy, edycja krytyczna, Hieronim Wierix, walka duchowa Keywords: Wacław Potocki, the knight of Christ, critical edition, Hieronymus Wierix, spiritual warfare 
http://rcin.org.pl 